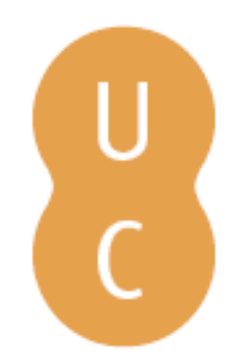

\title{
nombalina
}

\section{Os mais verdadeiros testemunhos da Batalha de Aljubarrota: os ossos dos seus combatentes}

\author{
Autor(es): $\quad$ Cunha, Eugénia; Marques, Carina; Matos, Vítor Manuel Aguiar e \\ Publicado por: Imprensa da Universidade de Coimbra \\ URL \\ persistente: URI:http://hdl.handle.net/10316.2/32666 \\ DOI: $\quad$ DOI:http://dx.doi.org/10.14195/978-989-26-0331-5_4 \\ Accessed : $\quad$ 26-Apr-2023 11:45:49
}

A navegação consulta e descarregamento dos títulos inseridos nas Bibliotecas Digitais UC Digitalis, UC Pombalina e UC Impactum, pressupõem a aceitação plena e sem reservas dos Termos e Condições de Uso destas Bibliotecas Digitais, disponíveis em https://digitalis.uc.pt/pt-pt/termos.

Conforme exposto nos referidos Termos e Condições de Uso, o descarregamento de títulos de acesso restrito requer uma licença válida de autorização devendo o utilizador aceder ao(s) documento(s) a partir de um endereço de IP da instituição detentora da supramencionada licença.

Ao utilizador é apenas permitido o descarregamento para uso pessoal, pelo que o emprego do(s) título(s) descarregado(s) para outro fim, designadamente comercial, carece de autorização do respetivo autor ou editor da obra.

Na medida em que todas as obras da UC Digitalis se encontram protegidas pelo Código do Direito de Autor e Direitos Conexos e demais legislação aplicável, toda a cópia, parcial ou total, deste documento, nos casos em que é legalmente admitida, deverá conter ou fazer-se acompanhar por este aviso.

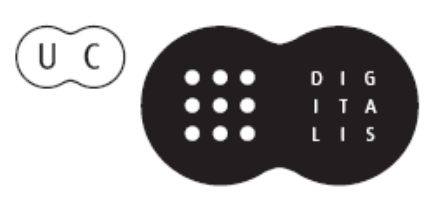




\section{Aljubarrota Revisitada}

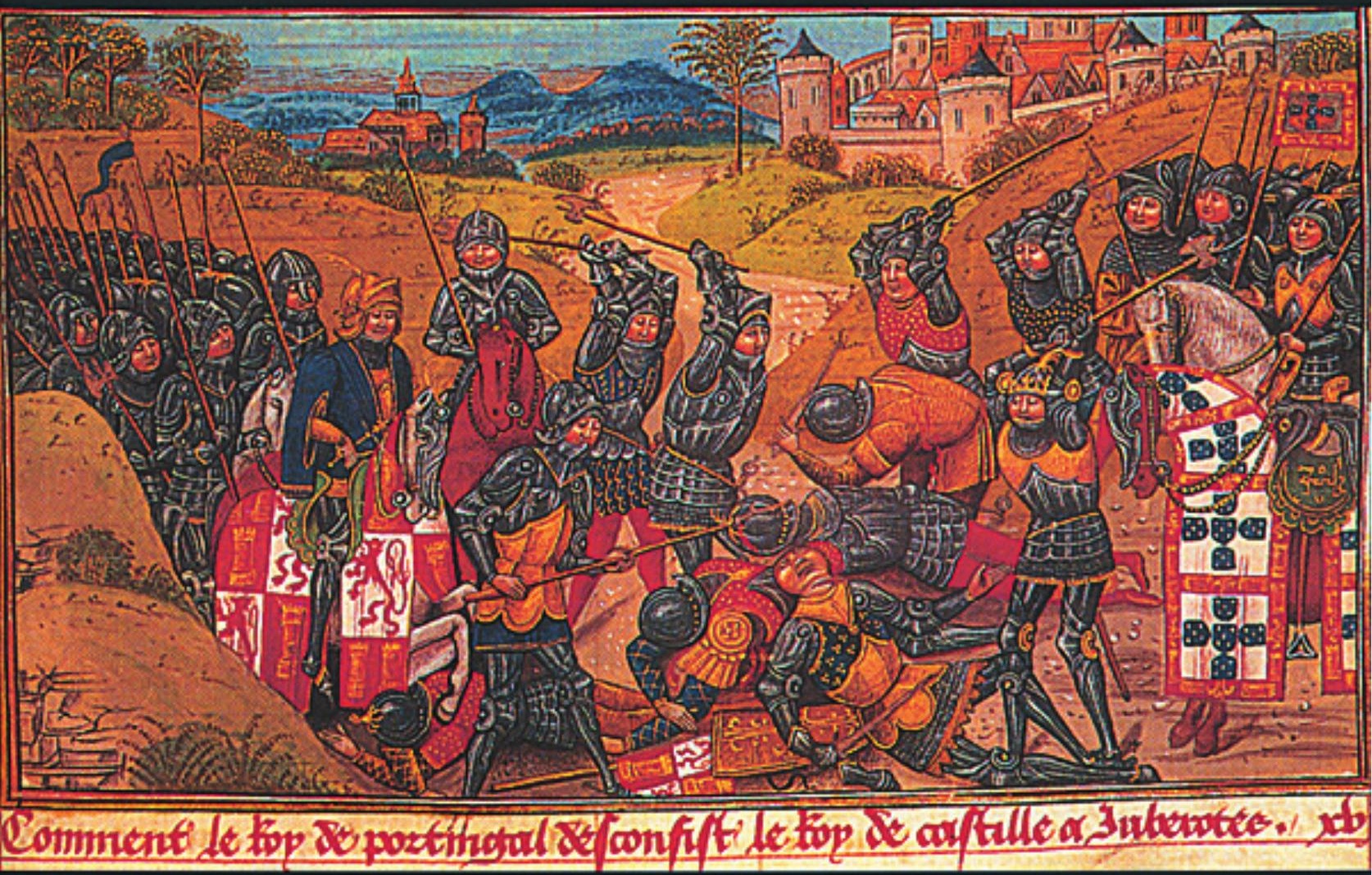


(Página deixada propositadamente em branco) 


\title{
JOÃO GOUVEIA MONTEIRO \\ Coordenação
}

\section{Aljubarrota Revisitada}

\author{
AUTORES \\ João Gouveia Monteiro \\ Fernando Pedro Figueiredo \\ Lídia Catarino \\ Helena Catarino \\ Eugénia Cunha \\ Carina Marques \\ Vitor Matos
}




\author{
COORDENAÇÃo EDITORIAL \\ Imprensa da Universidade de Coimbra \\ CONCEPÇÃO GRAFICA \\ António Barros \\ INFOGRAFIA \\ António Resende \\ Estimulus [design] • Coimbra \\ EXECUÇÃO GRÁFICA \\ G.C. - Gráfica de Coimbra, Lda. \\ Palheira - Assafarge - Apart. 3068 \\ 3001-453 Coimbra Codex
}

\title{
ILUSTRAÇÃO DA CAPA
}

Batalha de Aljubarrota. lluminura das Chroniques d'Angleterre, de Jean de Wavrin. Século XV. Londres, British Museum.

ISBN

972-8704-00-3

DEPÓSITO LEGAL

|67843/0|

@ \ JULHO 200I, IMPRENSA DA UNIVERSIDADE DE COIMBRA
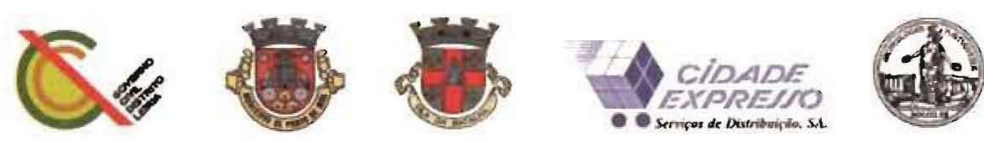

OBRA PUBLICADA COM O PATROCINIO DE:

GOVERNO CIML DE LEIRIA, CÁMARA MUNICIPAL DE PORTO-DE.MOS, CÅMARA MUNICIPAL DA BATALHA, CIDADE EXPRESSO - SERVIÇOS DE DISTRIBUIÇAO. S.A. E ASSOCIACAO DOS ARQUEOLOGOS PORTUGUESES 


\section{EUGENIA CUNHA * \\ CARINA MARQUES * \\ VITOR MATOS *}

\section{OS MAIS VERDADEIROS TESTEMUNHOS \\ DA BATALHA DE ALJUBARROTA: \\ OS OSSOS DOS SEUS COMBATENTES}

Nos últimos anos, tem-se vindo a constatar um interesse crescente pela paleobiologia dos esqueletos humanos provenientes de contextos históricos. Tornou-se, assim, imperativo conhecer, através da perspectiva paleobiológica, um pouco mais acerca dos combatentes da batalha de Aljubarrota, cujos restos humanos foram exumados de uma vala comum descoberta nos finais dos anos 50 por Afonso do Paço. No interior desta vala, os arqueólogos depararam com o cenário de um amontoado de ossos dispersos e misturados, correspondentes a uma inumação secundária (PAÇO, 1962, passim). Uma vez exumado o espólio osteológico, o mesmo foi depositado e preliminarmente estudado no Instituto de Antropologia (hoje designado como Museu Antropológico) da Universidade de Coimbra (PAÇO,1962, passim). Depois de um outro estudo antropológico preliminar, muito mais recente (CUNHA e SILVA, 1997), justificava-se plenamente uma análise exaustiva, cujos resultados aqui apresentamos.

\section{Objectivos}

Os objectivos deste estudo centram-se, assim, na reconstrução de alguns parâmetros "da vida" dos combatentes de Aljubarrota. Depois de quantificado o efectivo de indivíduos presentes, tentar-se-á obter o respectivo

(*) Departamento de Antropologia da Faculdade de Ciências e Tecnologia da Universidade 
perfil demográfico: distribuição por grupos etários e proporção sexual. No que se refere aos aspectos morfológicos, avaliar-se-á a robustez e estimar-se-á a estatura. Uma vez feita a despistagem das alterações tafonómicas, proceder-se-á a uma exaustiva análise paleopatológica, que visará detectar, não só episódios de doença ocorridos em vida dos indivíduos, mas também acontecimentos traumáticos peri-mortem ${ }^{(1)}$ passíveis de terem provocado a morte. Cumpridos estes objectivos, esperamos ter contribuído para um melhor conhecimento dos actores desta célebre batalha.

\section{$3.1 \bigcirc$ material osteológico}

\subsubsection{Cronologia}

De modo a confirmar a cronologia do espólio em estudo, recorreu-se à técnica de datação absoluta por ${ }^{14} \mathrm{C}$ (no laboratório Beta Analytics Inc., em Miami), efectuado sobre a matéria orgânica de duas tíbias, que foram seleccionadas aleatoriamente. Os resultados apontam claramente para o período compreendido entre 1290 e 1425 anos (sendo a época de maior probabilidade a de 1350 ( \pm 50 anos). (2)

O espólio em análise é composto por um total de 2874 ossos humanos, que terão correspondido a um número mínimo de 414 indivíduos (valor este estimado com base no fémur esquerdo) (Fig. 3.1).

Como pode ser observado na Fig. 3.2, existe uma fragmentação que atinge os 100\% em quase todos os ossos, o que implica que existam maioritariamente ossos incompletos (sem todas as suas porções). Na Tabela 3.I , confirma-se que a composição da amostra é bastante heterogénea, na medida em que as maiores frequências de ossos presentes são conseguidas pelos ossos longos, designadamente os fémures e as tíbias.

Em oposição, há uma nítida sub representatividade de ossos de pequeno tamanho, tais como costelas, vértebras e ossos dos pés e das mãos. Conforme se explicará mais à frente, a representatividade óssea detectada

\footnotetext{
(1). Fenómenos ocorridos na altura da morte dos individuos.

(2). Ver certificados de datação em anexo ( 1 e 2).
} 
Número mínimo de indivíduos

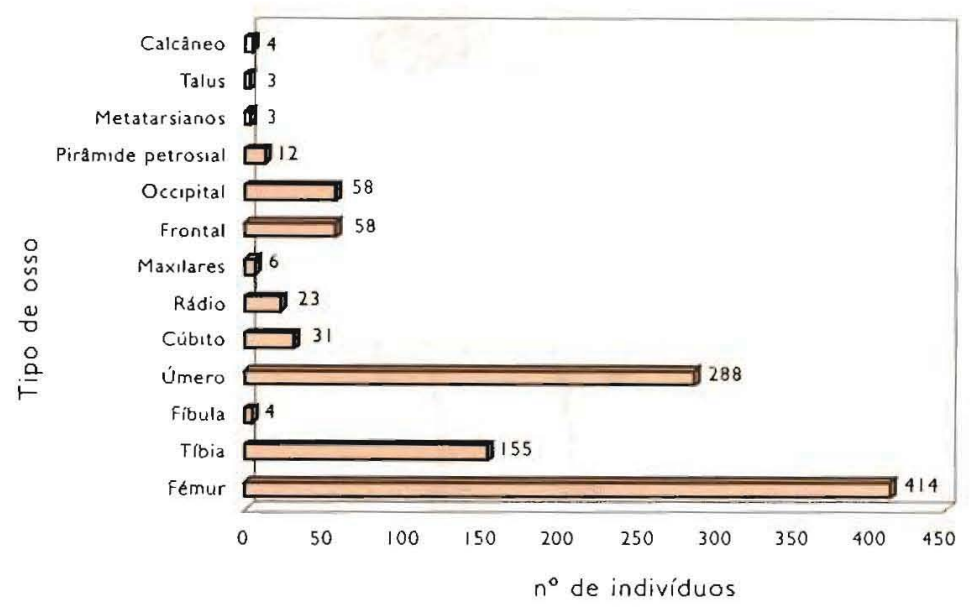

Fig. 3.1 - Número mínimo de indivíduos, estimado com base em diferentes ossos. O maior número mínimo é conseguido pelo fémur.

será uma consequência directa de uma recolha diferencial dos elementos ósseos que se encontravam dispersos no campo de batalha.

\subsubsection{Estado de conservação do material}

Através da análise da Fig. 3.2 (onde estão patentes as percentagens de fragmentação por tipo de osso), torna-se também notório que a grande maioria dos ossos estava fragmentada; os ossos completos são, portanto, 


\section{Percentagem de Fragmentação}

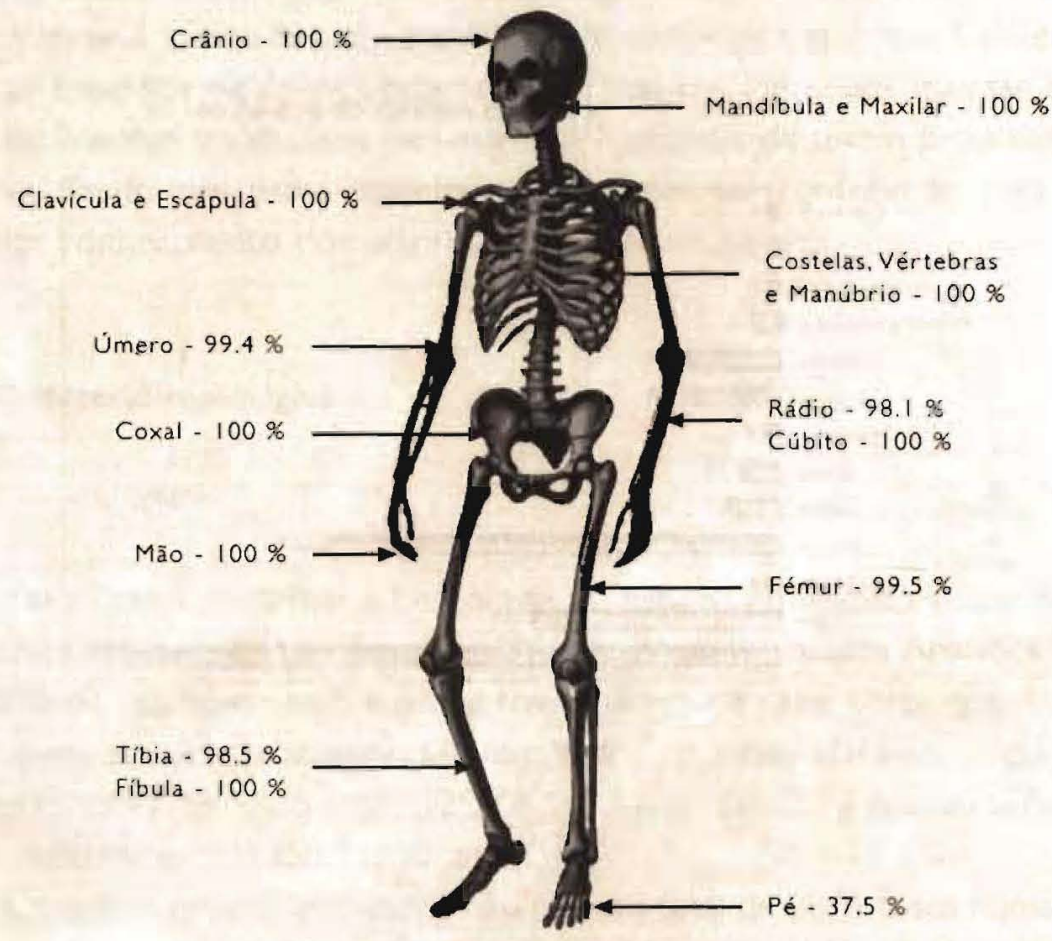

Fig. 3.2 - Esqueleto com os valores das percentagens de fragmentação.

uma excepção. Esta situação ter-se-á ficado a dever à aç̧ão de elementos tafonómicos, que serão discutidos no capítulo respectivo. A fragmentação do material, a composição diferencial da amostra e a fraca representatividade (Tabela 3.1) da série relativamente ao quantitativo total de combatentes presentes na batalha são elementos limitativos do estudo em curso. No entanto, apesar de não representarem senão uma pequena porção dos combatentes e de os ossos estarem fragmentados, a raridade de espólio osteológico do contexto de batalhas torna a série osteológica de Aljubarrota uma mais-valia internacional, tanto a nível antropológico como histórico. 
Tabela 3.I - A representatividade de cada osso na amostra, em termos de percentagens e valores reais. Destaque para os valores mais significativos e para os ossos em escasso número.

\begin{tabular}{lcc}
\hline Osso & $\begin{array}{c}\text { Percentagem } \\
\text { da amostra }\end{array}$ & $\begin{array}{c}\text { Número de fragmentos existentes } \\
\text { / Número total de ossos na amostra }\end{array}$ \\
\hline Crânio & $16.6 \%$ & $478 / 2874$ \\
Mandibula e maxilar & $2.43 \%$ & $70 / 2874$ \\
Escápula & $0.17 \%$ & $5 / 2874$ \\
Clavícula & $0.1 \%$ & $3 / 2874$ \\
Costelas & $0.93 \%$ & $27 / 2874$ \\
Vértebras & $1.28 \%$ & $37 / 2874$ \\
Esterno & $0.7 \%$ & $2 / 2874$ \\
Úmero & $18.9 \%$ & $544 / 2874$ \\
Rádio & $1.87 \%$ & $54 / 2874$ \\
Cúbito & $2.4 \%$ & $69 / 2874$ \\
Ossos da mão e metatarsianos & $0.21 \%$ & $6 / 2874$ \\
Coxal & $1.28 \%$ & $37 / 2874$ \\
Sacro & $0.14 \%$ & $4 / 2874$ \\
Fémur & $35.9 \%$ & $1023 / 2874$ \\
Tíbia & $14.7 \%$ & $422 / 2874$ \\
Fíbula & $1.25 \%$ & $36 / 2874$ \\
Ossos do pé & $1.67 \%$ & $48 / 2874$ \\
\hline
\end{tabular}

Acrescente-se que o valor desta série é ainda aumentado pelo facto de se terem reunido condições ímpares de concretização de um estudo interdisciplinar.

Por outro lado, o conjunto de ossos humanos disponíveis para análise antropológica, não obstante constituir um quantitativo importante e raro de obter para as populações do passado, está, ainda assim, longe de poder ser considerado como plenamente representativo da batalha em causa. A tomar como credíveis algumas das referências e interpretações históricas (OLIVEIRA, 1988, pp. 99-103), dos cerca de três a quatro mil indivíduos supostamente mortos no campo de batalha, os aqui analisados antropologicamente não são mais do que 414 (representam apenas 10.4 a $13.8 \%$ do 
total das baixas). Para além disso, trata-se claramente, conforme referido, de um ossário - conjunto de ossos, neste caso completamente desarticulados, objecto de, pelo menos, dois locais de inumação. Acrescente-se a agravante de, muito provavelmente, durante vários anos de deposição no campo de batalha estes ossos terem sido objecto da acção de factores tafonómicos extrínsecos (agentes agressores do meio) particularmente adversos à conservação dos ossos. Posteriormente, aquando da sua transferência para a "vala comum", terá havido uma clara selecção das peças ósseas de maior tamanho: os ossos longos. Estes, para além de maiores dimensões, têm a particularidade de ter uma forma mais regular, o que constitui uma clara vantagem quando comparados com ossos de forma irregular como o crânio e a bacia, dos quais, como seria de esperar no contexto tafonómico de Aljubarrota, não se preservaram quaisquer exemplares intactos. De realçar que o estudo de conservação e da representatividade diferencial dos vários ossos do esqueleto se, por um lado, constituem um factor limitativo para a análise paleobiológica pretendida, por outro, são positivamente relevantes, na medida em que, ao fornecerem dados úteis para a reconstrução do ambiente post-mortem (depois da morte dos indivíduos), corroboram os dados históricos relativamente ao destino dos ossos imediatamente após a morte.

Ou seja, e clarificando um pouco melhor o objecto que serviu de estudo ao relatório aqui apresentado, trata-se de um conjunto de ossos humanos, maioritariamente incompletos, fragmentados e com fortes alterações tafonómicas. É aqui pertinente relembrar que mais erro é introduzido pela omissão de um fragmento do que pela sua inclusão (UBELAKER, 1989), pelo que é de esperar que a análise deste conjunto de fragmentos venha, ainda assim, a revelar dados inéditos. Esta é, portanto, uma excelente oportunidade de provar a utilidade antropológica de fragmentos ósseos.

\subsection{Análise tafonómica}

Foram analisados 1999 ossos do esqueleto pós-craniano, mais 478 fragmentos cranianos, o que perfaz um total de 2477 ossos, que foram observados e registados numa base de dados. Acrescente-se que existiam 
mais 397 fragmentos ósseos, cujas reduzidas dimensões levaram à sua exclusão da base de dados.

A análise tafonómica (análise dos elementos do meio que causaram destruição e preservação dos ossos depois da morte do indivíduo) dos restos humanos da batalha de Aljubarrota requer uma breve nota justificativa da grande importância deste tipo de análise para qualquer estudo paleobiológico. Importância essa que é particularmente acrescida neste caso concreto, pelo facto de os ossos terem ficado expostos durante algum tempo. Efectivamente, os ossos que não são enterrados logo após a morte do indivíduo estão expostos a muito mais forças destrutivas, sendo o seu potencial de preservação reduzido. Uma série que esteve exposta, durante alguns anos, antes de ser enterrada, pode não ter representados quaisquer ossos pequenos devido à maior vulnerabilidade deste tipo de osso à acção de animais e das alterações ambientais (são estes os principais factores tafonómicos pesquisados).

Há, assim, que entender previamente os processos de metamorfose que os ossos sofreram depois da morte dos indivíduos a que pertenceram (que é a análise tafonómica). Só uma vez feita a despistagem destes tipos de alterações é que se torna legítimo reconstruir a vida a partir do esqueleto.

As chances de conservação de um determinado osso resultam de um equilibrio de duas forças antagónicas: a destruição e a preservação. Cada uma destas forças depende de vários atributos, que, de um modo geral, se podem classificar como extrínsecos e íntrinsecos ao indivíduo. Dentro do primeiro tipo, o ambiente abiótico, através do $\mathrm{pH}$ do solo e da água, por exemplo, têm uma influência preponderante. Por outro lado, o ambiente biótico abrange as outras espécies que habitam a área na qual o indivíduo morreu, as quais podem consumir, morder, quebrar, ajudando assim na decomposição ou dispersão dos ossos.

A representação diferenciada dos ossos de Aljubarrota permite inferir a existência de condições tafonómicas menos favoráveis: apenas numa série que foi rapidamente enterrada podemos esperar ter uma grande quantidade de ossos completos.

É de realçar o facto de não terem sido recuperados quaisquer ossos particularmente ricos em tecido esponjoso. Efectivamente, e analisando a Tabela 3.1, torna-se óbvio que foram os ossos mais compactos que melhor resistiram aos predadores e necrófagos. Aliás, conforme se irá demonstrar, 
a proporção de ossos completos e fragmentados fornece indícios das forças destrutivas específicas a que estiveram sujeitos os ossos dos combatentes.

$\mathrm{Na}$ Tabela 3.2 estão patentes os resultados da análise tafonómica no esqueleto pós craniano, com discriminação dos vários tipos de factores que em seguida irão ser tratados mais detalhadamente. Os fragmentos cranianos analisados apresentam ausência de marcas de animais, sendo os factores ambientais os preponderantes.

Tabela 3.2 - Acção dos vários factores tafonómicos nos ossos do esqueleto pós-craniano ( $n^{\circ}$ de ossos com alterações tafonómicas $/ n^{\circ}$ total de ossos observados).

Fenómeno tafonómico

Factores Ambientais

Abrasão

Raízes / Microorganismos

Animais
Percentagem

$96.9 \%$

$(1938 / 1999)$

$23.4 \%$

$35.8 \%$

$(468 / 1999)$

(7/5/1999)

$45.4 \%$

\subsection{A acção dos animais}

Em geral, a actividade dos carnívoros, dos roedores e muitas vezes também dos herbívoros, não se inicia quando o corpo ainda está em decomposição, já que "existe uma certa relutância por parte dos carnívoros em consumir porções de corpos recentemente mortos" (GALLOWAY, 1989), mas apenas na sua fase de esqueletização, o que pode demorar alguns meses (GALLOWAY,1989).

140 A prevalência de marcas de dentes num conjunto de ossos reflecte a quantidade de tempo que os ossos estiveram expostos antes do enterramento e a densidade populacional das espécies responsáveis pelas marcas.

As marcas de animais nos ossos de Aljubarrota foram cuidadosamente observadas em laboratório. Variam desde pequenas fossas paralelas, provavelmente feitas por micro mamíferos em geral (ratos), até grandes 
marcas provocadas por grandes mamíferos. Num estado intermédio ficam animais como os cães domésticos, os lobos, as raposas, etc. A percentagem de marcas de animais na nossa amostra, 45,4\%, (Tabela 3.2) é bastante elevada. Segundo SERJEANTSON (I99|) "proporções superiores a $25 \%$ em material arqueológico reflectem que os ossos foram alimento para cães" (SERJEANTSON, 199I, p. 80).

A alta frequência de marcas de carnívoros, no espólio de Aljubarrota, corrobora a permanência dos corpos à superfície durante bastantes meses, antes de um enterramento definitivo. A acção dos animais era mais frequente na extremidade das diáfises dos ossos longos, onde são visíveis as marcas das mordeduras de vários animais, como carnivoros, roedores e artiodáctilos. Estas marcas tanto incluíam evidências de incisivos (cut marks) como de toda a dentição (chewing), ou seja, para além das marcas em si, o próprio osso sofreu um certo achatamento (Fig. 3.3).

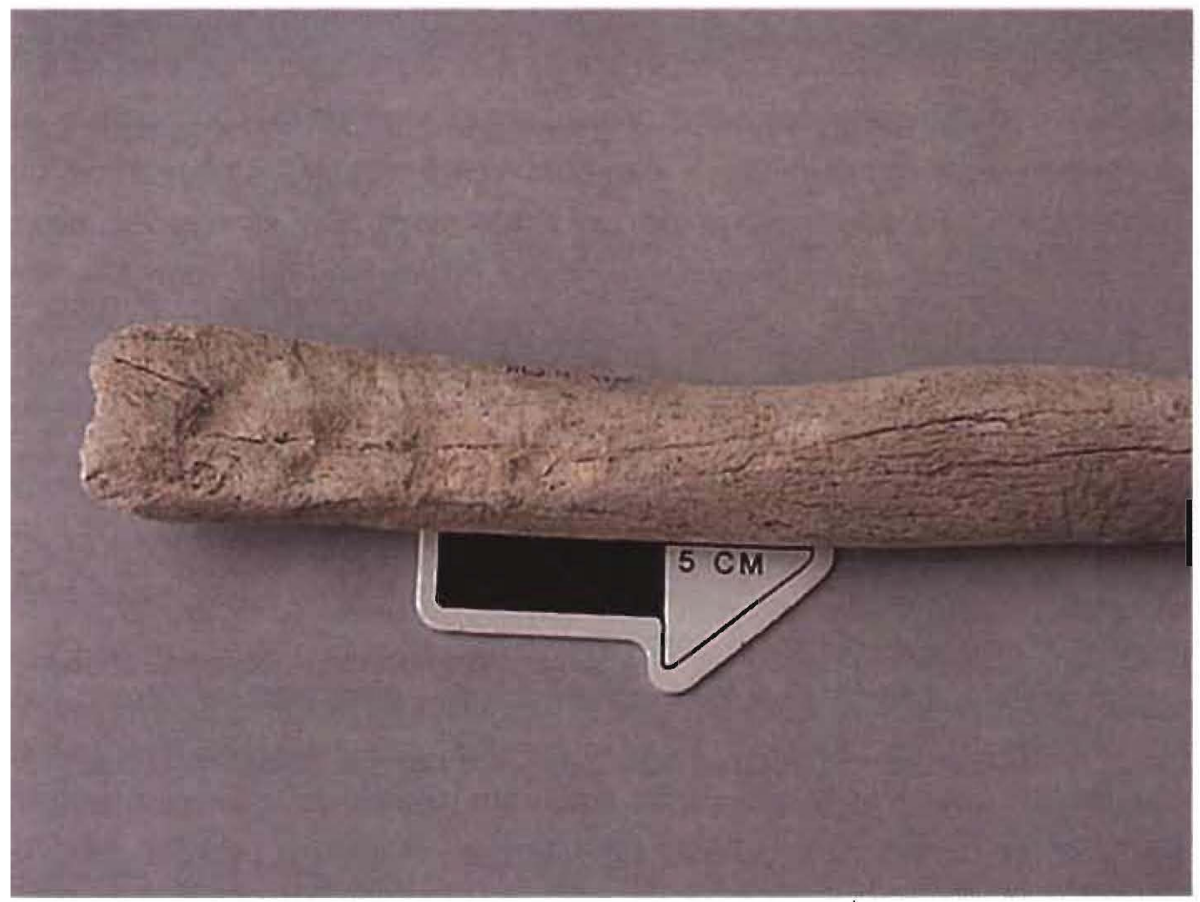

Fig. 3.3 - Osso com grande destruição da sua diáfise, devido à acção tafonómica dos animais (marca de chewing). 
A identificação precisa das várias espécies de predadores activos em Aljubarrota não é possível, devido à sobreposição, num mesmo osso, de vários factores tafonómicos.

Outro tipo de fauna, designadamente alguns insectos como as térmites e algumas larvas de escaravelhos, terá também deixado a sua marca, na forma de pequenos buracos redondos ou rastos de vermes.

Acrescente-se que os roedores, para além das mordeduras, terão igualmente tido um papel determinante, na medida em são particularmente hábeis em deslocar e remover pequenos ossos do seu sítio original de depósito. GALLOWAY (1989) refere, inclusivamente, que são encontrados muitos elementos do esqueleto em ninhos de ratos existentes perto dos locais de deposição.

\subsubsection{Meio Ambiente, Raízes e Microorganismos}

A acção dos diversos factores ambientais traduz-se na destruição das várias partes que estiveram expostas a esses elementos. Os ossos e os dentes podem ser sujeitos a elevadas temperaturas, congelados ou humedecidos. Particularmente no caso dos ossos não enterrados, estes processos quebram-nos lentamente e, eventualmente, destróem-nos. De referir que a severidade da acção dos factores ambientais está directamente relacionada com o tempo de exposição dos ossos, agindo o ambiente de formas diferentes em diferentes micro-ambientes.

A exposição ao meio ambiente (sol, chuva, vento, temperatura) pode ser quantificada em fases de 1 a 6, segundo o modelo de Bhrensmeyer (1978, in UBELAKER, 1997). As últimas fases correspondem a uma acção mais severa e duradoura do meio ambiente.

142 A grande maioria dos ossos de Aljubarrota enquadra-se dentro das últimas fases deste modelo, traduzido por fendas e esfoliação (Fig. 3.4), o que implica que os ossos em análise estiveram sujeitos ao ar livre por longos períodos de tempo (GALLOWAY, 1989, passim). A elevada percentagem de efeitos ambientais na superfície dos ossos em análise, 96,9\% (Tabela 3.2), apoia mais uma vez a ideia de estes terem sofrido processos de decomposição à superfície do solo. 


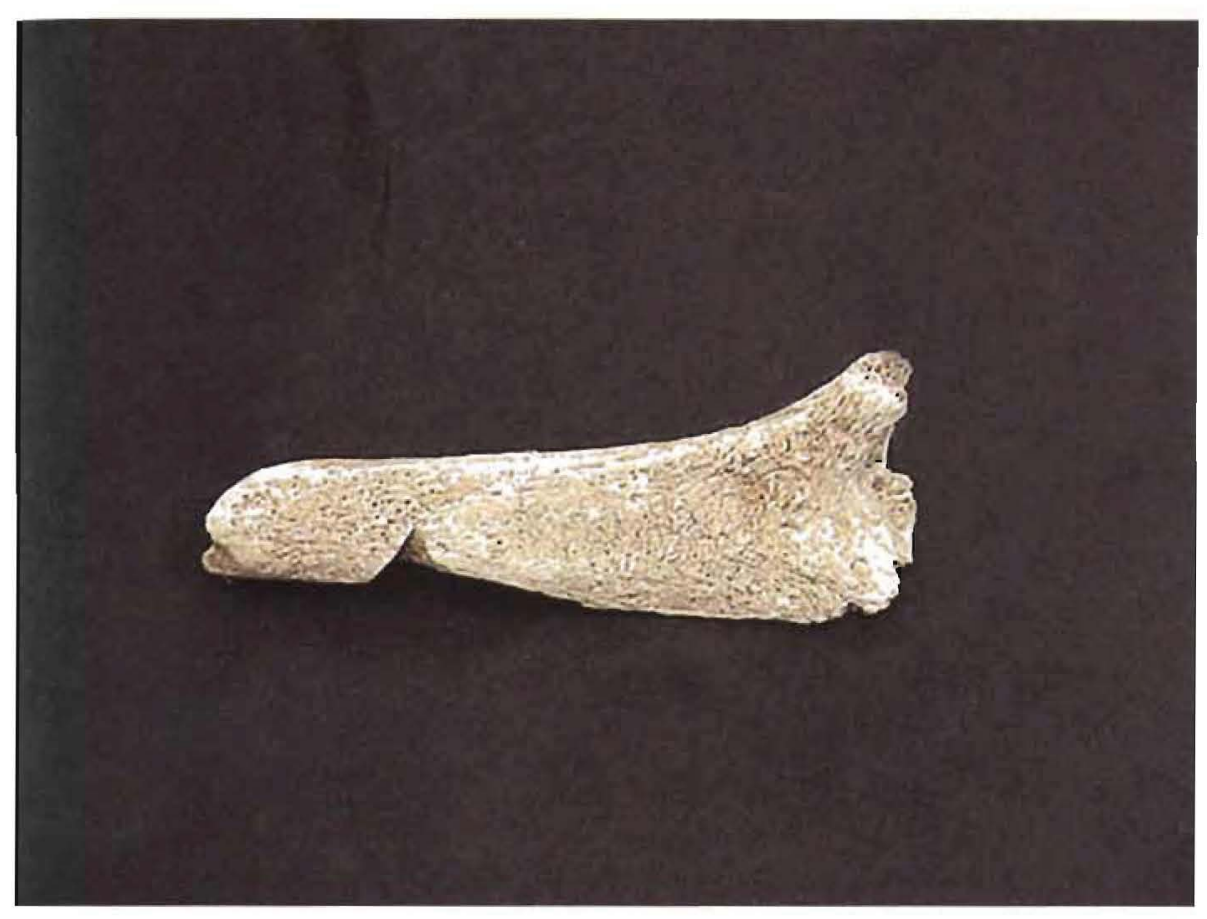

Fig. 3.4 - Fragmento de osso com alguma esfoliação, devido à acção dos factores ambientais.

Não deixa de ser curioso que também a incidência de marcas de raízes e de microorganismos( ${ }^{(3)}$ (35,8 \%) suportem as ideias anteriores. As raízes, durante o processo de captação de água e minerais do solo, libertam exsudados de natureza ácida, que contribuem para a destruição da superfície do osso.

Alguns ossos longos adquiriram uma cor acastanhada e manchas, com total remoção de periósteo, cuja etiologia não foi possivel estabelecer.

Outros ossos, designadamente oito fémures, apresentavam também manchas brancas, derivadas de exposição ao sol num período já de pós- descarnamento (UBELAKER, 1997, passim). Do total de fragmentos de fémur analisados $(n=998), 8(0,8 \%)$ apresentavam exposição ao sol.

(3). Normalmente são organismos detritivoros (alimentam-se de restos de matéria orgânica em decomposição) que vivem na manta morta dos solos (Colêmbulos, Ácaros, algumas larvas de insectos). 
Finalmente, são também de referir os efeitos produzidos nos ossos pelo impacto do vento - ou de partículas transportadas pela água, que se traduzem na abrasão e numa certa porosidade. No caso dos ossos em questão, os rebordos das zonas fragmentadas e as zonas com cristas anatómicas tornaram-se arredondados, e nos casos de abrasão mais severa deu-se inclusivamente remoção da superfície exterior do osso - o periósteo. Devido à dificuldade em distinguir os diferentes graus de abrasão, apenas foram utilizados como critérios de classificação a sua ausência ou presença.

\subsection{Análise paleodemográfica}

\subsection{Diagnose sexual}

Uma investigação de esqueletos não identificados inclui a determinação do sexo, baseada essencialmente em características dos ossos coxais e, secundariamente, do crânio (FEREMBACH et al, 1980). Dado que estas regiões anatómicas não se encontravam preservadas (com excepção de algumas glabelas ${ }^{(4)}$, apenas foi possível recorrer a análises métricas dos ossos longos, que, contudo, não puderam ser aplicadas a todos os elementos do esqueleto, visto que requerem a preservação de regiões específicas, que muitas vezes não se encontravam disponíveis. Com o objectivo de maximizar a informação sobre diagnose sexual, foram medidos todos os talus e calcâneos (SILVA, 1995, passim), as tíbias (BRUZEK, 1991, passim) os úmeros (CARRETERO et al, 1995, passim) e os fémures (TAMAGNINI e VIEIRA DE CAMPOS, 1949, passim) da série.

Os resultados obtidos foram, no entanto, muito exíguos, visto que, apesar de a maioria das glabelas apontarem para indivíduos masculinos, as glabelas per se não permitem diagnósticos sexuais fidedignos. Quanto aos resultados da análise métrica, do total de 45 ossos em que era possível fazer medições, pelo menos $77.7 \%$ eram masculinos. Tão pouco a observação das

(4). A glabela é uma região anatómica do crânio acima das órbitas, que fornece algumas indicações sexuais. 
zonas de inserção muscular puderam informar sobre a proporção sexual. Efectivamente, eram muito poucos os ossos que permitiam, ora uma quantificação da robustez, ora uma análise credível das enteses( 5 ).

\subsubsection{Estimativa da idade à morte}

O outro parâmetro fundamental para a caracterização das populações do passado é a obtenção do respectivo perfil demográfico. A idade à morte dos esqueletos adultos é, no entanto, um dos grandes problemas da paleodemografia: os métodos existentes não apresentam a correlação desejável com a idade à morte real.

Para os indivíduos adultos, os elementos mais reveladores do processo de senescência são as metamorfoses sofridas pela superfície auricular e pela sínfise púbica do osso coxal (LOVEJOY et al., 1985, passim). Porém, e mais uma vez, não foi encontrada nenhuma destas regiões anatómicas preservadas, pelo que foi inviabilizada qualquer análise mais credível da idade à morte. Consequentemente, fomos instigados a recorrer aos seguintes indicadores etários: a densidade de massa óssea nas epífises proximais do fémur e do úmero (visível pelo exame radiológico); o desgaste dentário diferencial; e a patologia degenerativa. Estes elementos sugerem a inexistência, na nossa amostra, de indivíduos muito idosos. A visualização de determinadas linhas de fusão entre epífises e diáfises sugere a existência de adultos jovens (18-25 anos), enquanto que a ausência de patologias degenerativas severas e de $3 .^{\circ}$ molares com grau máximo de desgaste exclui a hipótese de existirem indivíduos com uma idade à morte superior a 65 anos ${ }^{(6)}$. Ou seja, os indicadores etários disponíveis apenas permitem obter um perfil etário muito geral: a série será constituída maioritariamente por indivíduos com idades compreendidas entre os 18 e 65 anos.

(5). Entese: zona de inserção muscular.

(6). A fraca credibilidade dos indicadores etários para idades mais avançadas, aliada ao facto de as zonas ósseas necessárias para o efeito não existirem na série de Aljubarrota, não nos permitem ser mais precisos quanto ao limite etário superior. Tanto pode ser 55,60 como 65 anos. 
Referência ainda para a detecção de alguns ossos de não adultos (com idades compreendidas entre os 4-7 anos: UBELAKER, 1989, passim), que claramente destoam do contexto em causa. A explicação mais plausivel para a sua presença no ossário reside, muito provavelmente, na sua inclusão ocasional no local de inumação secundário, durante o processo de trasladação dos corpos do campo de batalha para a vala comum.

\subsection{Aspectos morfológicos}

\subsection{Estatura}

A avaliação da estatura é classicamente obtida a partir do comprimento dos ossos longos, que apresentam uma excelente correlação com a estatura em vida. Apenas dispúnhamos de 25 fémures em condições de permitir o cálculo da altura. Ainda assim, só 5 destes estavam completos. Para os restantes, foi necessário aplicar a metodologia de SANTOS (1993), para obter o comprimento total do osso, medida que foi então utilizada na equação de regressão escolhida para o cálculo estatural (OLIVIER et al., 1978, passim). Foram obtidos valores médios de estatura de $1,65 \mathrm{~m}$ e $1,70 \mathrm{~m}^{(7)}$ (OLIVIER et al., 1978, passim), respectivamente para os fémures direitos e esquerdos. Apesar do fraco efectivo do espólio ósseo de Aljubarrota, não poderíamos deixar de comparar os resultados com outras séries coevas. Ressalta, através da Tabela 3.3, que os resultados obtidos estão de acordo, avaliados com os demais.

No entanto, não queremos deixar de destacar a detecção de sete indivíduos particularmente altos, com estaturas superiores a $1.75 \mathrm{~m}$. Não estando em causa a existência de indivíduos altos na época medieval (CUNHA, 1999, passim), poderá não ser casual a existência de vários indivíduos altos no campo de batalha. Apesar desta hipótese não passar disso mesmo e só poder ser confirmada pela obtenção de um número significativamente maior de estaturas, cremos que este facto poderá sugerir a selecção de alguns indivíduos mais altos para combatentes.

(7). Com desvio padrão de $9,3(n=11)$ e $7,3(n=\mid 4)$, respectivamente. 
Tabela 3.3 - Valores médios da estatura, por sexos, para algumas séries de necrópoles medievais ibéricas (in CUNHA e CRUBÉZY, 2000.). Sendo d.p. = desvio padrão e $\mathrm{N}=$ número de fémures.

\begin{tabular}{|c|c|c|c|c|c|c|c|}
\hline População & $\times$ masc. & d.p. & $N$ & $x$ fem. & d.p. & $N$ & Método \\
\hline Canac & 167 & 6.8 & 14 & 154.8 & 2.4 & 12 & Manouvrier, 1893 \\
\hline S. J. A. & 165.7 & 4.3 & 18 & 153.4 & 4.9 & 14 & Olivier et al., 1978 \\
\hline La Olmeda & 163.5 & 5.4 & 69 & 157.1 & 3.95 & 47 & Olivier et Tissier, 1975 \\
\hline Burgos & 168 & & 51 & & & & Olivier et Tissier, 1975 \\
\hline Logrono & 168 & & 26 & 157 & & & Olivier et Tissier, 1975 \\
\hline La Torrecilla & 167 & & & 150.6 & & & $\begin{array}{l}\text { Olivier et Tissier, 1975; } \\
\text { Manouvrier (in Olivier, 1960) }\end{array}$ \\
\hline S. M. Hito & 168 & 6.8 & & 159 & 6.9 & & \\
\hline Catalunha & 170 & & & 157 & & & \\
\hline Sta. Eulalia & 166 & & 79 & 157 & & 39 & Trotter et Gleser, 1952 \\
\hline S. J. Momoitio & 170 & 0.05 & 17 & 155 & 0.05 & 12 & Trotter-Gleser, 1952 \\
\hline Prazo & 168.2 & 4.2 & 5 & 156.9 & 5.4 & 3 & Olivier et al., 1978 \\
\hline S. Pedro Canaferrim & 164.2 & 4.29 & 4 & 150.1 & 2.14 & 3 & Olivier et al., 1978 \\
\hline Maiorca & 161.7 & 4.8 & 3 & 156.3 & 2.07 & 2 & Olivier et al., 1978 \\
\hline
\end{tabular}

\subsection{Análise paleopatológica}

De todos os tipos de patologias (doenças) passiveis de deixar vestígios nos ossos, os mais relevantes para o contexto em questão são os de índole traumática. De facto, os ossos recuperados evidenciam episódios relacionados com trauma. É de relembrar que, efectivamente, apenas uma percentagem das agressões vividas pelos indivíduos deixa vestígios nos ossos, e isto porque a maioria das lesões afecta em exclusivo os tecidos moles, sendo os ossos, em geral, o último sistema a ser afectado pelas doenças. 


\subsection{Patologia traumática}

A procura de vestígios de traumatismos de guerra nos ossos é um domínio estimulante da paleopatologia, porque a sua forma e localização traduzem informações preponderantes para esclarecer os episódios da vida e da morte dos indivíduos (PÁLFI, 1997, p. 37).

O trauma é compreendido como uma lesão do tecido vivo (tecidos moles e ósseos), causado por uma força ou mecanismo extrínseco ao corpo (LOVELL, 1997, p.|39), podendo englobar fracturas, deslocações, incisões e perfurações, as quais serão tratadas caso a caso.

Para a patologia traumática foram observadas e registadas as características patológicas de cada osso, num total de 1999 fragmentos de ossos longos e 478 ossos do crânio.

A análise paleopatológica foi feita recorrendo a métodos macroscópicos, lupa binocular e, sempre que necessário, raios $X$.

Neste espólio ósseo de Aljubarrota, distinguiram-se categorias individuais, nomeadamente fracturas antigas (ou seja, fracturas que os indivíduos sofreram muito tempo antes de combaterem nesta batalha), deslocamentos, incisões elou cortes e perfurações sofridos peri-mortem (estas duas últimas categorias evidenciam lesões sofridas na altura da morte do indivíduo). Estas duas últimas categorias são também designadas como fracturas penetrantes, que resultam da aplicação de uma grande força numa pequena área. Exemplos destes traumas são as lesões causadas por uma espada ou um machado-de-guerra (levando a incisões/cortes), pela ponta de uma seta ou de um virotão, ou por uma lança (causando perfurações ou depressões) (LOVELL, 1997, p. 140).

É bastante importante, para compreender a descrição das lesões, perceber claramente a diferença entre as fracturas detectadas neste espólio

148 e aquelas que se podem detectar, em geral, nos esqueletos. De um modo geral, os esqueletos podem apresentar sinais de uma fractura que ocorreu no exacto momento da morte do individuo (peri-mortem), ou seja, quando um osso é fracturado e o indivíduo não sobrevive, os rebordos do osso partido apresentam-se lisos e sem evidências de remodelação óssea. Por outro lado, as fracturas antigas (que ocorreram muito tempo antes de o indivíduo ter sucumbido) podem ser diagnosticadas através dos calos ósseos, 
dos hematomas e através de alterações severas na morfologia do osso, que, quando possível, podem ser confirmadas através da análise radiológica. Neste espólio dos combatentes, não foram encontradas quaisquer evidências de fracturas do primeiro tipo referido, ou seja, peri-mortem. Não porque os indivíduos não tenham fracturado pernas ou braços durante o combate, mas sim porque as vicissitudes que estes restos humanos sofreram, entre a morte dos indivíduos e a recuperação dos ossos, terão eliminado os eventuais vestígios desta patologia traumática peri-mortem. Percebe-se que, quando os ossos são enterrados, armazenados e manipulados, ficam com as suas extremidades mais destruídas, logo, a indicação de uma fractura recente, que como já foi referido, consta de rebordos delimitados sem qualquer remodelação óssea, é facilmente destruída. Por outro lado, nas fracturas antigas, como já ocorreu a cicatrização da lesão, as porções fracturadas já se uniram através do calo ósseo, logo, é mais fácil a sua preservação e identificação, mesmo com a intensa destruição a que estes restos ósseos são sujeitos. Fica então clara a ressalva de que, ao longo deste trabalho, a tipologia fractura corresponde sempre a fracturas antigas e remodeladas.

Contudo, ao contrário das fracturas peri-mortem, das quais não se registaram vestígios, a maioria das incisões e perfurações que ocorreram na altura da morte (peri-mortem) preservaram-se até hoje e foram bastante esclarecedoras para compreender os eventos da batalha. Uma razão para que os cortes ou incisões sofridos pelos indivíduo na batalha se tenham preservado, e as fracturas, que também terão ocorrido na batalha, não se tenham registado, poderá ter a ver com o seguinte. As fracturas implicam, normalmente, a quebra total do osso e a subsequente separação em segmentos independentes, que se podem perder mais facilmente. Quanto aos cortes, estes, porque raramente penetraram totalmente o osso, deixam marcas mais perenes.

Uma vez registadas as lesões, estas foram codificadas de modo a permitir a criação de uma base de dados para tratamento estatístico. Este foi feito através do programa SPSS, que permitiu o cálculo das frequências das lesões e a avaliação de possíveis correlações (o qui-quadrado e o teste de Fisher foram alguns dos testes aplicados).

Para além deste registo, efectuámos descrições detalhadas de casos patológicos particulares. 
Resultados da análise da patologia traumática no esqueleto pós-craniano

A fig. 3.5a demonstra a ocorrência de lesões traumáticas, em termos de percentagem total, pela sua tipologia-fractura antiga, deslocamento, incisões (também pequenas depressões semelhantes a incisões) e perfurações em todo o esqueleto, à excepção das lesões cranianas. A fig. 3.5b expõe um esqueleto humano, onde se pode observar a distribuição da patologia traumática por cada tipo de osso, com os respectivos valores percentuais, apenas no que respeita ao esqueleto pós craniano (ou seja, não inclui o crânio).

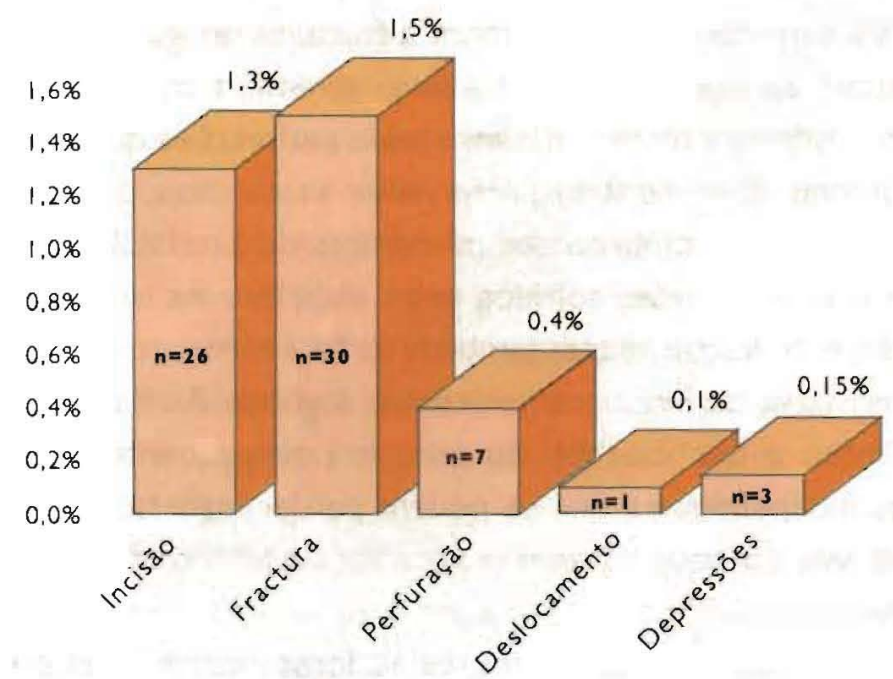

Fig. 3.5a - Percentagem das patologias observadas num total de 1999 (N) fragmentos de ossos longos. 
Destaca-se a ausência total de lesões traumáticas nos ossos do antebraço, rádio e cúbito (Fig. 3.5b). Para os ossos afectados, torna-se evidente que são bastante baixas as percentagens de patologia traumática (Fig. 3.5b) em cada tipo de osso, para além de pouco representativas.

Entre os ossos analisados, a tíbia e o fémur são os que apresentam maior incidência de lesões patológicas traumáticas (Fig. 3.5b). Porém, enquanto que os tipos de lesões mais frequentes a nível dos fémures e úmeros são as incisões, nas tíbias são mais frequentes as fracturas já

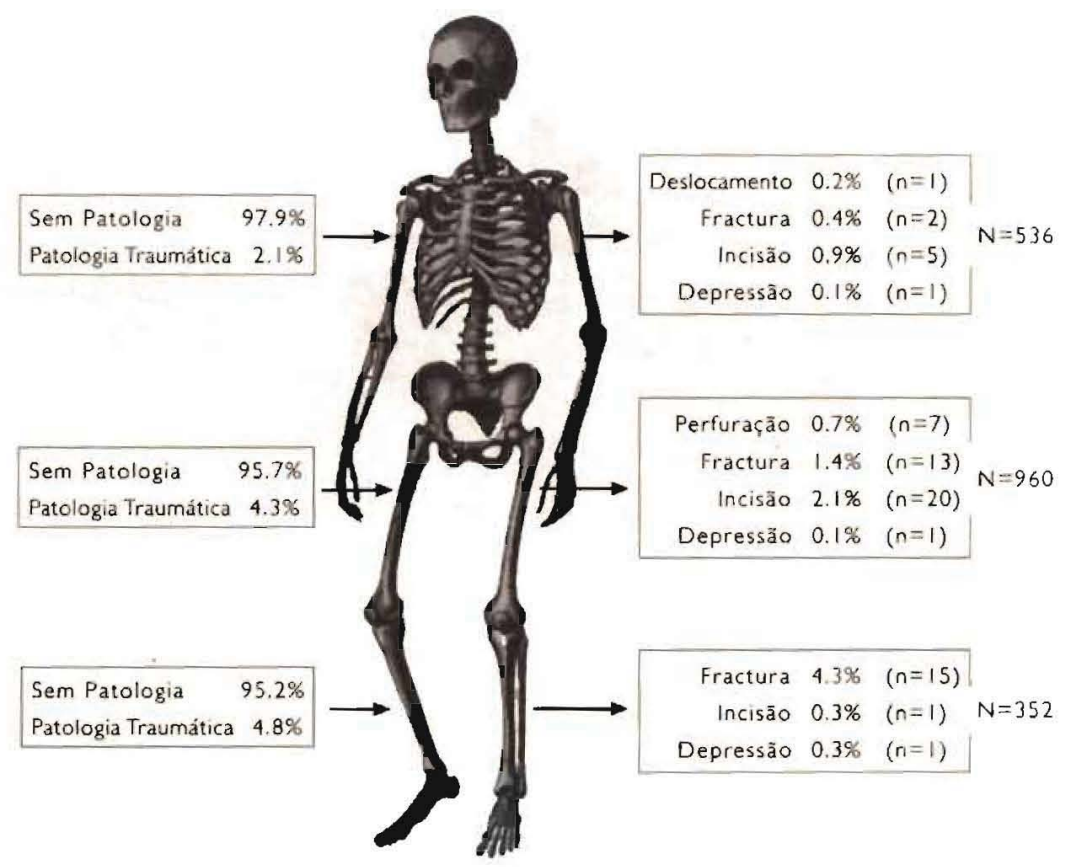

Fig. 3.5b - Esquema de distribuição das lesões traumáticas, em que n representa o número de lesões existentes, na totalidade de ossos pesquisados ( $N$ ). 
remodeladas (como pode ser confirmado na fig. 3.5b) ${ }^{(8)}$. Os resultados apontam para uma maior incidência de fracturas nos membros inferiores, dado igualmente constatado numa série de cavaleiros medievais húngaros (séc. X) analisados por PÁLFI e DUTOUR (1996). Em termos gerais, não detectámos acentuadas diferenças entre os lados direito e esquerdo dos ossos, em relação ao total de lesões traumáticas pesquisadas (Fig. 3.6).

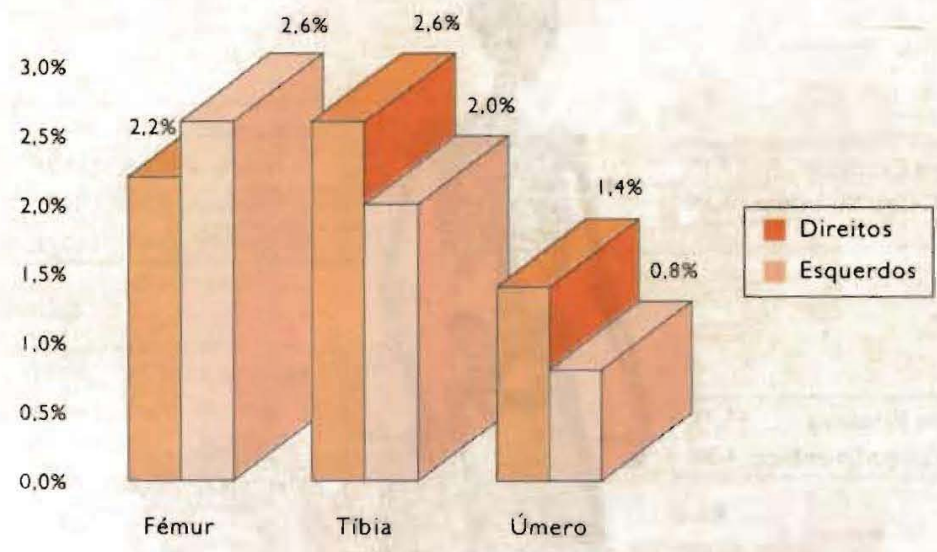

Fig. 3.6 - Frequência de patologia traumática dos ossos com diferente lateralidade.

(8). Note-se que apenas estamos a comparar frequências, porque neste caso não foi possível aplicar o teste de qui-quadrado, já que o número de casos era inferior ao requerido para aplicar correctamente este método. 
a) Incisōes

Se compararmos os nossos resultados, em termos de incisões, com uma das poucas batalhas coevas a nivel europeu cujo espólio foi estudado, a Batalha de Wisby, ocorrida em 136 I na ilha de Gotland (Suécia), a concordância é apenas parcial.

Ou seja, enquanto que em Aljubarrota as incisões incidem particularmente nos fémures e úmeros (Figs. 3.7 e 3.8), em Wisby as tíbias, logo seguidas pelos fémures, são os ossos mais atingidos pelos cortes.

A menor incidência deste tipo de lesões nos membros superiores é explicada pelo autor do estudo de Wisby (BO INGELMARK, in THORDEMAN et al., 1939) como devida à major protecção conferida pelos escudos aos braços. Aplicando este raciocínio ao nosso caso, é legitimo perguntar se em Aljubarrota os escudos não foram eficazes? A resposta poderá ser encontrada através da análise das lesões pela superfície do mesmo osso, o que será feito de seguida. Por outro lado, e continuando com as explicações propostas por THORDEMAN et al., (1939), teoricamente não é de esperar que o fémur seja muito afectado por incisões. Isto porque é o osso com maior camada muscular e dos restantes tecidos, o que faz com que sejam necessários ataques particularmente violentos para deixar marcas nele. Ora, sendo o fémur um dos ossos mais atingidos por incisões (Fig. 3.7) em Aljubarrota, torna-se legítimo supor que os golpes sofridos pelos combatentes terão sido de uma grande violência.

Quanto à distribuição das incisões pelos dois lados do esqueleto, mais uma vez, e aparentemente( ${ }^{(9)}$, não existem diferenças acentuadas na lateralidade das incisões, o que exclui um ataque preferencial por um dos lados. Poderá isto querer dizer que terá havido uma certa confusão e pressa no combate?

Para consubstanciar a análise da lateralidade foi ainda feita uma análise da distribuição das lesões consoante a superfície do osso: anterior, posterior, lateral e medial, no geral e em cada um dos lados. Nos ossos lesados com

(9). Uma vez mais, o tratamento estatístico recorrendo ao qui-quadrado revelou-se impraticável, logo, apenas recorremos à comparação de frequências. 


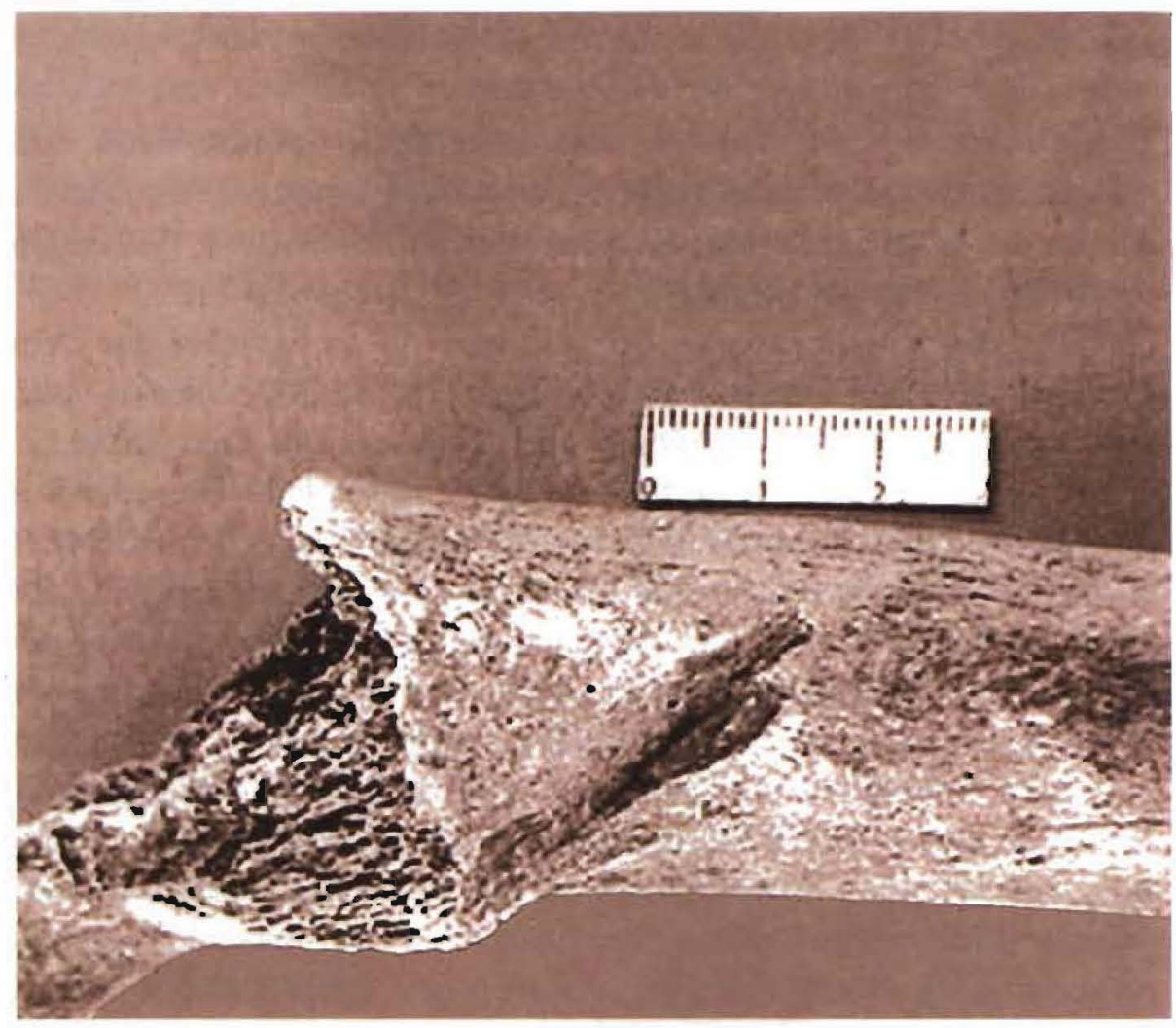

Fig. 3.7 - Lesão por corte/incisão num fémur direito.

incisões, estas localizam-se preferencialmente na região posterior do osso, seguido da região postero-medial e postero-lateral.

Subdividindo por lateralidades, percebe-se que, nos ossos do lado direito, a maioria das lesões são no lado posterior, enquanto que nos esquerdos, para além do lado posterior, há também uma grande incidência de lesões na face anterior. Estas diferenças são, contudo, ligeiras, comprovando-se para o fémur (o único onde foi possível a comprovação estatística, já que era o único osso para o qual existia uma amostra suficiente) que esta diferença não era estatisticamente significativa.

Independentemente da sua lateralidade, constatou-se ainda que as diáfises são invariavelmente muito mais afectadas que as epífises (extremidades do osso). Contudo, há que atender à fraca representatividade 


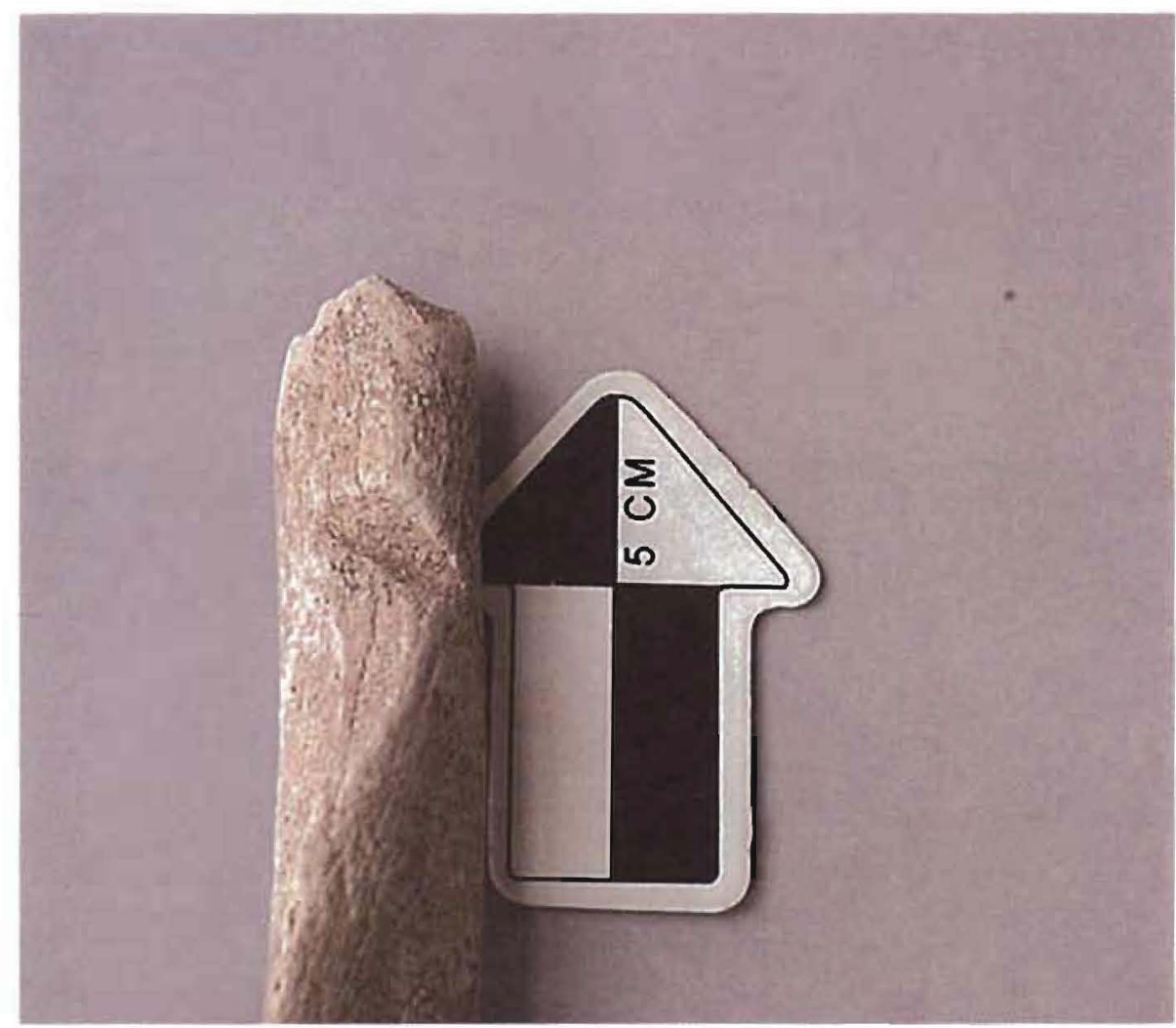

Fig. 3.8 - Lesão por corte/incısão na diáıise de um úmero.

da amostra em epífises dos ossos longos $(N=336)$ o que, conforme referido, se deverá a acção tafonómica.

b) Fracturas

As 30 (1.5\%) fracturas remodeladas (Fig. 3.5a) observadas distribuem-se sempre ao longo das diáfises, sem qualquer padrão específico. São casos de fracturas antigas, que estes indivíduos terão sofrido alguns anos antes da batalha de Aljubarrota. A análise radiológica não revelou nenhuma linha de fractura, porém, a maioria dos ossos apresentava sinais macroscópicos coincidentes com fracturas antigas (Figs. 3.9a e 3.9b). 


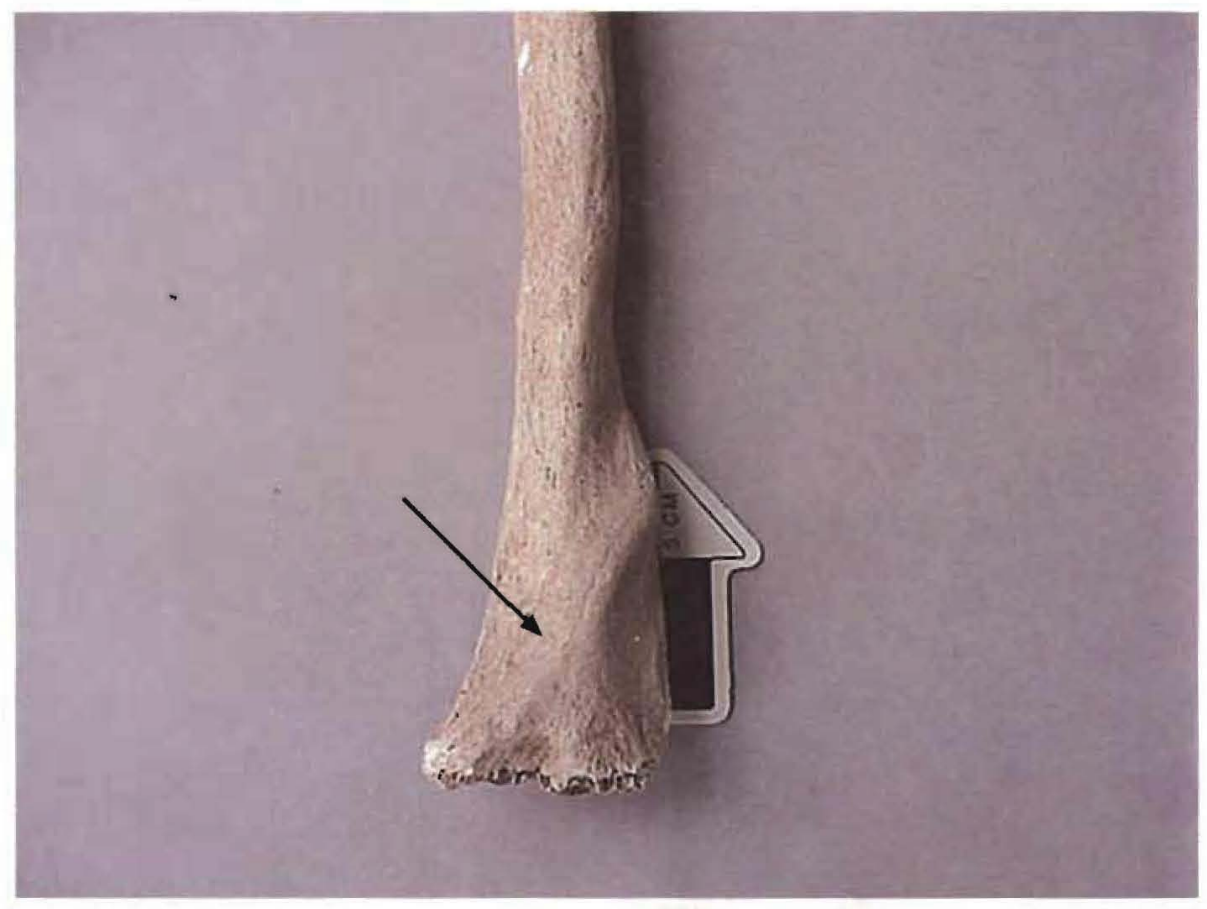

Fig. 3.9a - Fractura remodelada de um úmero direito.

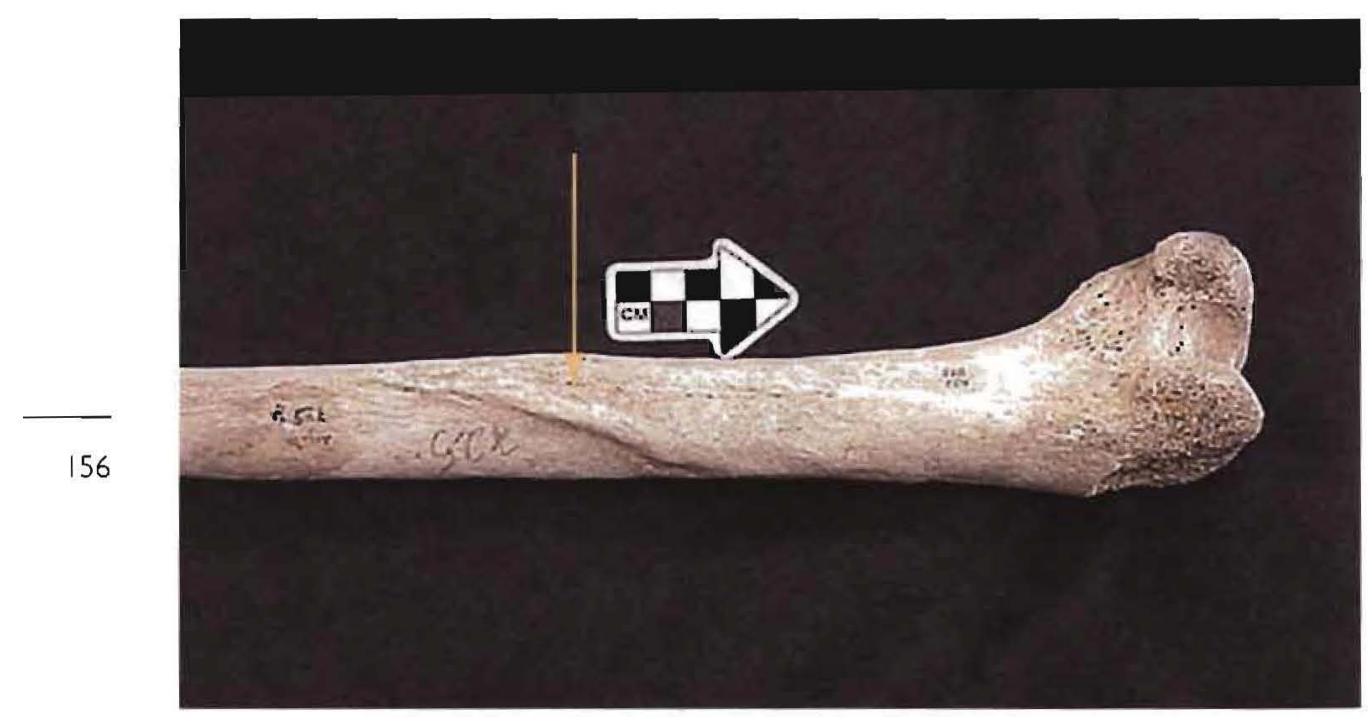

Fig. 3.9b - Fractura antiga num fémur direito. 
c) Perfurações

Foram detectadas 10 perfurações/depressões (Fig. 3.5a). A análise de lateralidade não revelou diferenças relevantes. Enquanto que as perfurações (Fig. 3.10) nos ossos direitos afectam predominantemente a região medial e a epífise proximal, nos esquerdos as perfurações localizam-se posterior e medialmente.

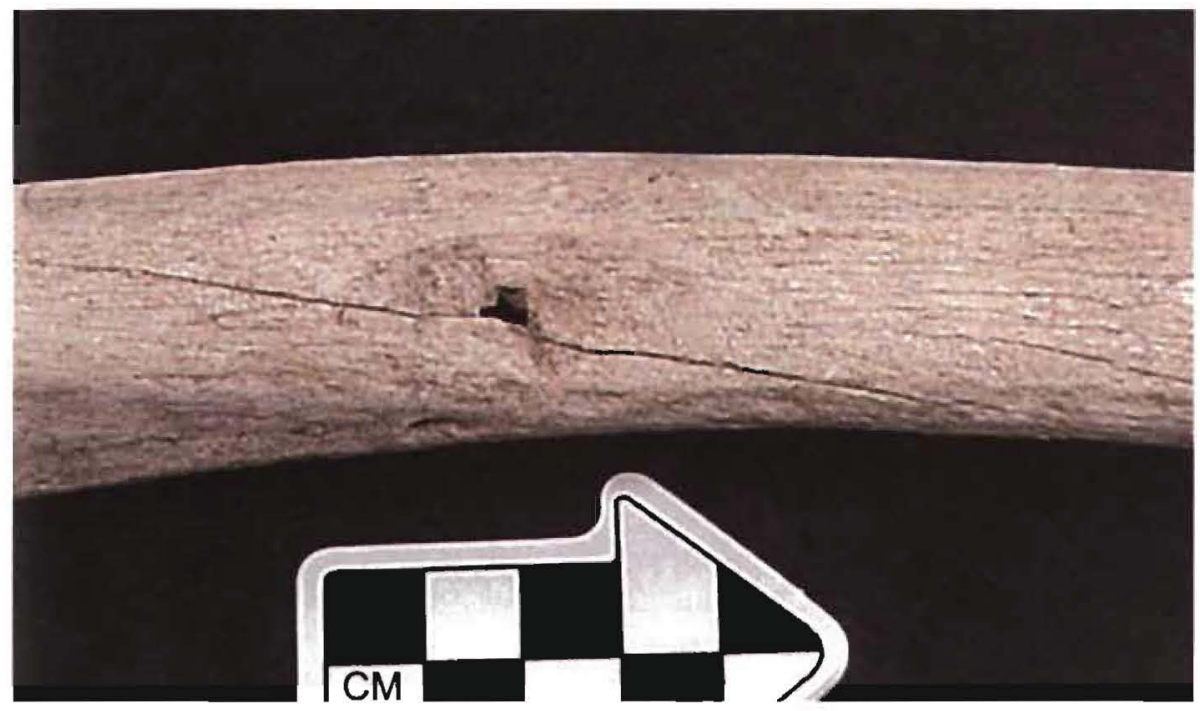

Fig. 3.10 - Evidências de uma perfuração (indicada pela seta), rodeada de muitas alterações post-mortem.

Resultados da análise da patologia traumática no crânio

À semelhança do esqueleto pós-craniano, as frequências de lesões observadas nos crânios são baixas. Num total de 478 fragmentos, observámos apenas 12 incisões (2.5\%) e 4 perfurações (0.84\%). Há que relembrar que a amostra consiste apenas em fragmentos cranianos mal preservados, sendo mesmo alguns deles impossíveis de identificar. Assim, dos 478 fragmentos existentes, apenas foi possível reconhecer 324 fragmentos cranianos (parietais, temporais, occipitais e frontais). 
a) Incisões

Há uma incidência semelhante de incisões nos ossos frontal e occipital, $3.7 \%(5 / 135)$ e $4.9 \%$ (4/82) respectivamente, frequências essas bastante superiores às dos parietais (0.93\% - 1/107). Quanto à dimensão, as incisões variam de 3 a $6 \mathrm{~cm}$ de comprimento, penetrando, no entanto, profundamente no osso. Registámos a existência de uma calote craniana (o único exemplar razoavelmente completo de um crânio), onde são observadas 3 incisões, uma em cada osso do crânio (frontal, parietal, occipital) (Fig. 3. II). De referir ainda um outro fragmento craniano de occipital e parietal, com duas incisões (Fig. 3.12).

As incisões poderão ter sido provocadas por espadas e por achas-de-armas. A análise comparativa com as outras (raras) séries osteoarqueo-

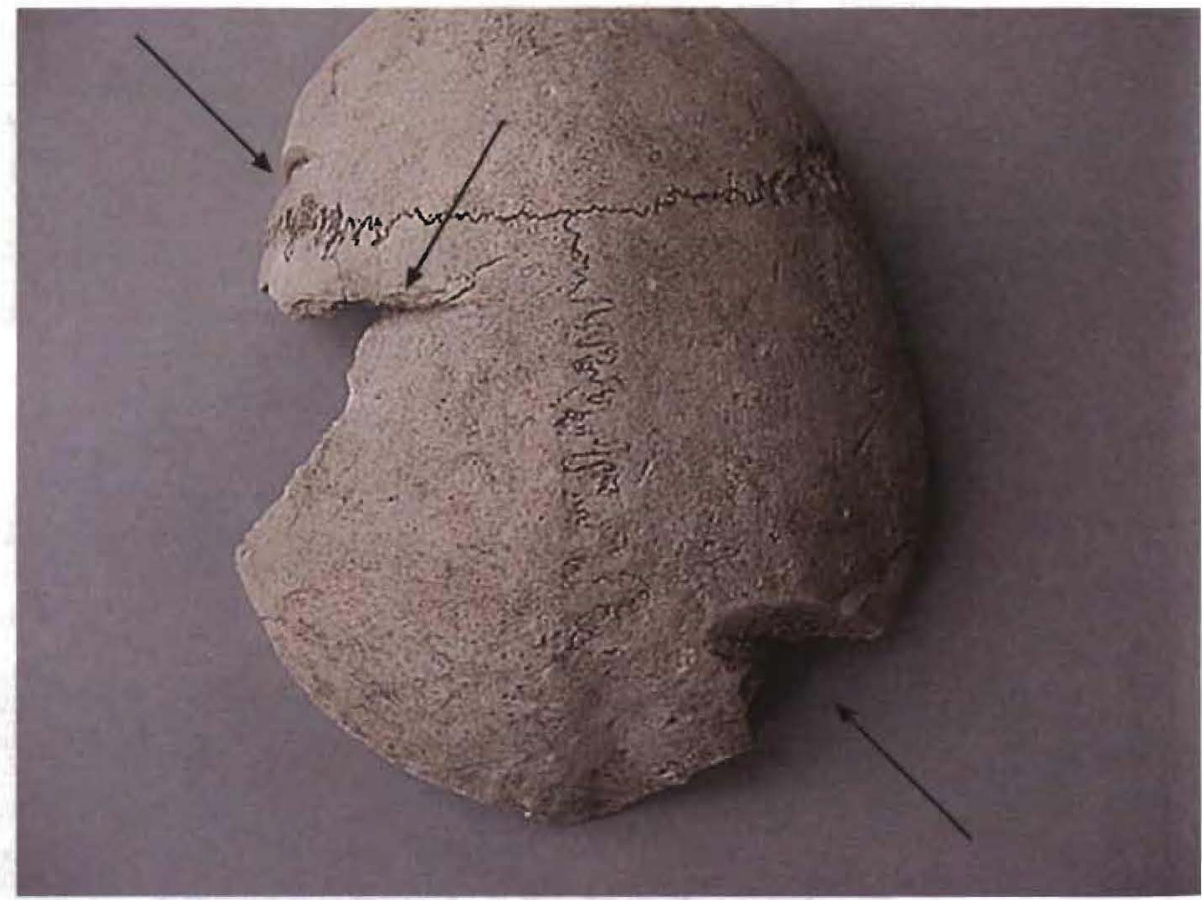

Fig. 3.II - Calote craniana evidenciando três cortes severos. 
lógicas de batalhas que deixaram espólio ósseo, como a de Wisby (THORDEMAN et al., 1939, passim), permite constatar diferenças, já que na batalha de Wisby houve uma maior incidência no parietal e menor no occipital.

Entre os ossos do crânio, os parietais, devido à sua maior área, são os locais propensos para serem afectados sempre que as lesões são causadas ao acaso. Para além disso, o osso frontal tem duas vezes mais resistência do que os outros ossos cranianos (WILKINSON, 1997, passim). Por outro lado, BO INGELMARK (in THORDEMAN et al., 1939) refere que, em Wisby, a maioria dos cortes no osso frontal foram causados por agressões dirigidas verticalmente e a partir de cima. Assim, e subscrevendo WILKINSON (1997) o facto de os parietais serem os ossos cranianos menos afectados invalida ataques ao acaso, enquanto que a relativamente maior frequência de lesões

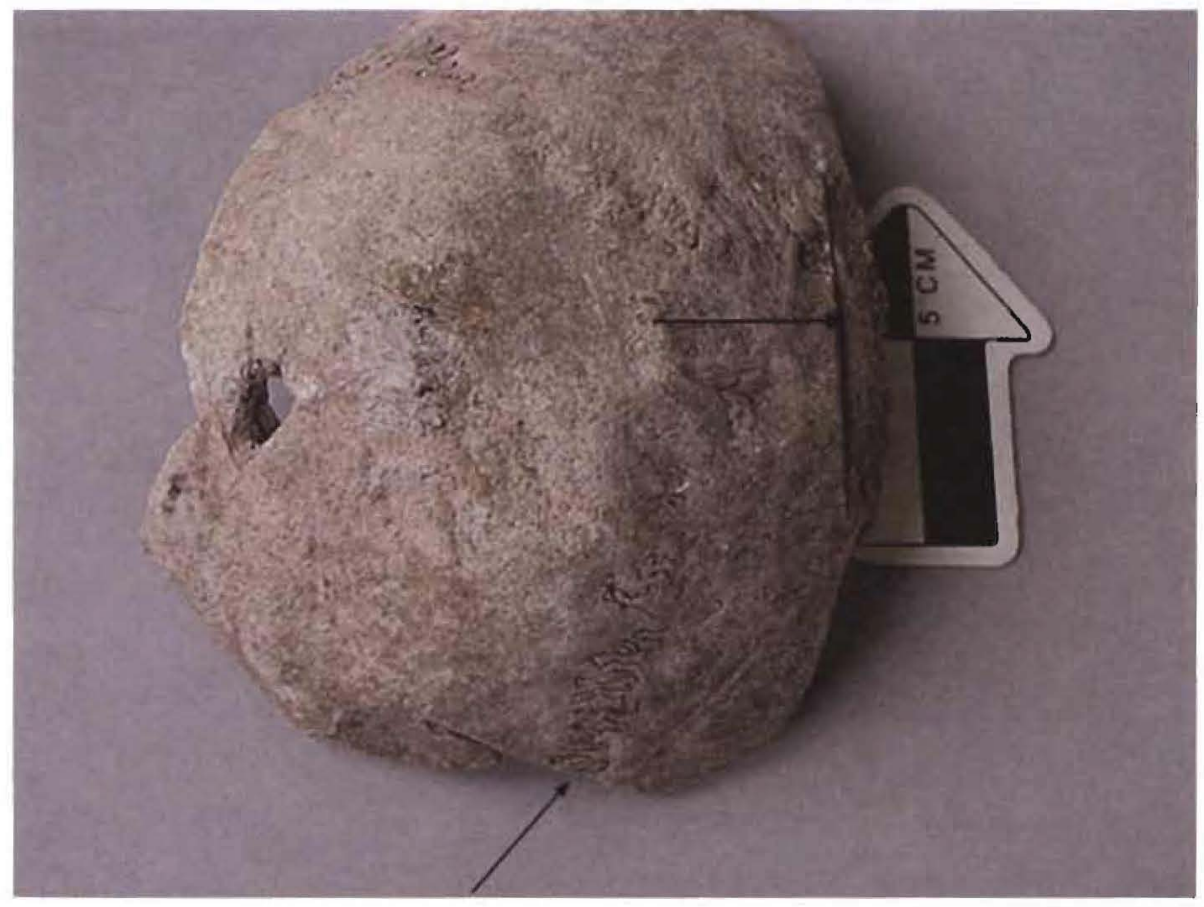

Fig. 3.12 - Fragmento craniano com duas incisões. 
no frontal sugere agressões direccionadas. Entretanto, na presente série, o occipital, não obstante o seu grande revestimento muscular, é também afectado, pelo que, e aplicando o raciocínio de BO INGELMARK (in THORDEMAN et al., 1939), o facto de ser atingido sugere uma clara insuficiência das proteç̧ões de cabeça e ainda que os ataques terão sido desferidos por trás, ou quando o indivíduo jazia no solo. No que se refere ao ataque pelo lado posterior do indivíduo, curiosamente, há acordo entre os dados cranianos e pós-cranianos.

b) Perfurações

As perfurações dividem-se bastante similarmente entre as várias regiões do crânio: 0.74\% (1//35); 0.93\% (1//07) e 1.2\% (1/82), respectivamente no frontal, no parietal e no occipital. Na fig. 3.13, observa-se uma perfuração

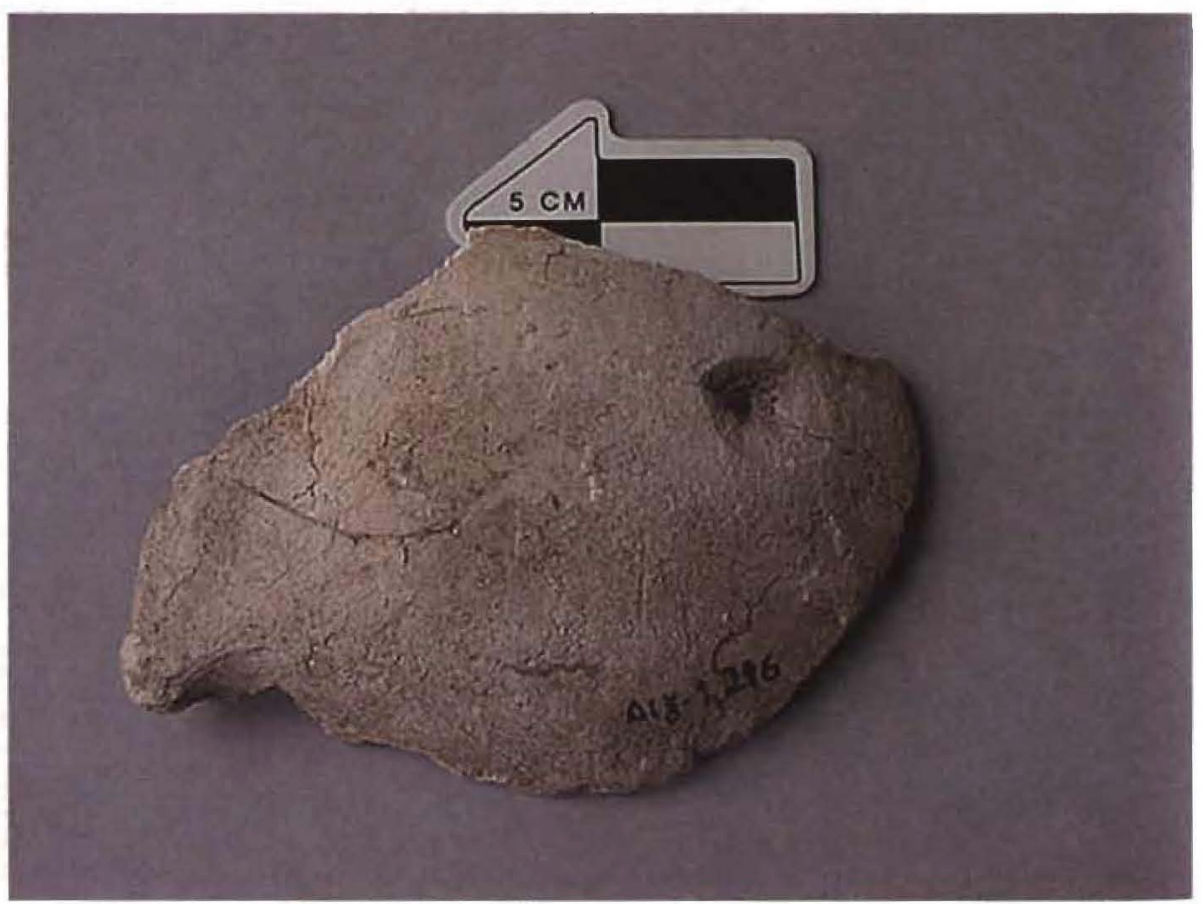

Fig. 3.13 - Frontal com perfuração. 
do frontal: apesar da destruição post mortem que rodeia a lesão, uma observação cuidadosa sugere tratar-se de uma lesão peri-mortem, por perfuração.

De um modo geral, dada a profundidade das perfurações, estes traumatismos foram certamente inferidos com bastante força e por objectos cortantes. A inexistência de sinais de remodelação óssea permite-nos sugerir que se trata de golpes coincidentes com a hora da morte. As perfurações terão resultado da agressão por setas, virotões, pedras de fundas, bicos de martelos de armas, pontas de lança, ou outras armas.

\subsubsection{Patologia degenerativa}

A patologia degenerativa é, juntamente com a oral e a traumática, uma das patologias mais frequentes nas populações humanas do passado (ROBERTS e MANCHESTER, 1995, p. I02), sendo bem conhecida do homem medieval, frequentemente por ela afectado.

A patologia degenerativa é geralmente um processo crónico e progressivo, que se vai desenvolvendo ao longo da vida dos indivíduos, tendo uma incidência mais elevada em indivíduos mais idosos. Na patologia degenerativa articular (artrose), um aspecto consensual na maioria dos estudos é que a sua etiologia é polifactorial; porém, a idade dos indivíduos é, indubitavelmente, uma das causas, sendo as alterações degenerativas na estrutura sinovial concomitantes com o processo de envelhecimento (PEYRON e ALTMAN, 1992, passim).

Em matéria de análise da patologia degenerativa não articular, são as entesopatias - lesões na zona de inserção muscular e tendinosa consideradas como os marcadores ósseos de actividade física que mais se têm salientado na osteoarqueologia (CUNHA e UMIBELINO,1995, passim). Segundo PÁLFI (1997), as entesopatias esclarecem-nos acerca de padrões de actividade, sempre que existe uma hipersolicitação de determinados músculos.

No que diz respeito à metodologia aplicada na pesquisa da patologia degenerativa, as lesões nas articulações foram classificadas segundo a escala de CRUBÉZY et al. (1985). 
Eram poucas as articulações disponíveis para pesquisa patológica: apenas alguns fémures, tíbias, úmeros, rádios, cúbitos, fibula e vértebras. Das 239 observações possíveis, só 7 apresentavam artrose (2.9\%). Através das Tabelas que se seguem, verifica-se que o número de ossos que preservaram os locais de pesquisa da patologia articular é extremamente reduzido, em relação ao número total de ossos presentes em laboratório. Este poderá ser um dos motivos da tão baixa incidência da artrose. Ainda assim, as regiões que pudemos apontar como mais afectadas são a coluna vertebral e os fémures.

\section{Tabela 3.4 - Incidência de artrose.}

Legenda: $N=$ número total de fragmentos ósseos existentes na nossa amostra

$N^{0}=$ número de ossos / região onde a artrose é pesquisável

$\mathrm{n}^{\circ}=$ número de ossos com registos de artrose

Proximal $=$ Extremidade articular superior

Distal $=$ Extremidade articular inferior

\begin{tabular}{|c|c|c|c|c|}
\multirow{2}{*}{$\begin{array}{c}\text { Fémur } \\
(\mathrm{N}=1023)\end{array}$} & $\begin{array}{c}|c| \\
\mathrm{n}^{\circ} \text { de ossos com artrose } \\
/ \mathrm{N}^{\circ} \text { observáveis }\end{array}$ & Percentagem & $\begin{array}{c}\mathrm{n}^{\circ} \text { de ossos com artrose } \\
/ \mathrm{N}{ }^{\circ} \text { observáveis }\end{array}$ & Percentagem \\
\hline Esquerdo & $0 / 21$ & $0 \%$ & $0 / 32$ & $0 \%$ \\
\hline Direito & $\mathrm{I} / 2 \mathrm{l}$ & $4.8 \%$ & $0 / 22$ & $0 \%$
\end{tabular}

\begin{tabular}{|c|c|c|c|c|}
\multirow{2}{*}{$\begin{array}{c}\text { Tíbia } \\
(\mathrm{N}=422)\end{array}$} & \multicolumn{2}{|c|}{ Proximal } & \multicolumn{2}{c|}{ Distal } \\
\cline { 2 - 5 } & $\begin{array}{c}\mathrm{n}^{\circ} \text { de ossos com artrose } \\
/ \mathrm{N}^{\circ} \text { observáveis }\end{array}$ & Percentagem & $\begin{array}{c}n^{\circ} \text { de ossos com artrose } \\
/ \mathrm{N}^{\circ} \text { observáveis }\end{array}$ & Percentagem \\
\hline Esquerdo & $0 / 16$ & $0 \%$ & $0 / 7$ & $0 \%$ \\
\hline Direito & $0 / 5$ & $0 \%$ & $0 / 9$ & $0 \%$
\end{tabular}

\begin{tabular}{|c|c|c|c|c|}
\multirow{2}{*}{$\begin{array}{c}\text { Úmero } \\
(\mathrm{N}=544)\end{array}$} & \multicolumn{2}{|c|}{ Proximal } & \multicolumn{2}{c|}{ Distal } \\
\cline { 2 - 5 } & $\begin{array}{c}\mathrm{n}^{\circ} \text { de ossos com artrose } \\
/ \mathrm{N}^{\circ} \text { observáveis }\end{array}$ & Percentagem & $\begin{array}{c}n^{\circ} \text { de ossos com artrose } \\
/ \mathrm{N}^{\circ} \text { observáveis }\end{array}$ & Percentagem \\
\hline Esquerdo & $0 / 2$ & $0 \%$ & $1 / 1 \mathrm{I}$ & $9.1 \%$ \\
\hline Direito & $0 / 3$ & $0 \%$ & $0 / 19$ & $0 \%$
\end{tabular}




\begin{tabular}{|c|c|c|c|c|}
\multirow{2}{*}{$\begin{array}{c}\text { Rádio } \\
(\mathrm{N}=54)\end{array}$} & $\begin{array}{c}|c| \\
n^{\circ} \text { de ossos com artrose } \\
/ \mathrm{N}^{\circ} \text { observáveis }\end{array}$ & Percentagem & $\begin{array}{c}n^{\circ} \text { de ossos com artrose } \\
/ \mathrm{N}^{\circ} \text { observáveis }\end{array}$ & Percentagem \\
\hline Esquerdo & $0 / 7$ & $0 \%$ & $0 / 2$ & $0 \%$ \\
\hline Direito & $0 / 1$ & $0 \%$ & $0 / 1$ & $0 \%$
\end{tabular}

\begin{tabular}{|c|c|c|c|c|}
\multirow{2}{*}{$\begin{array}{c}\text { Cúbito } \\
(\mathrm{N}=69)\end{array}$} & $\begin{array}{c}|c| \\
\mathrm{n}^{\circ} \text { de ossos com artrose } \\
/ \mathrm{N}^{\circ} \text { observáveis }\end{array}$ & Percentagem & $\begin{array}{c}\mathrm{n}^{\circ} \text { de ossos com artrose } \\
/ \mathrm{N}^{\circ} \text { observáveis }\end{array}$ & Percentagem \\
\hline Esquerdo & $0 / 4$ & $0 \%$ & $0 / 0$ & $0 \%$ \\
\hline Direito & $0 / 9$ & $0 \%$ & $0 / 0$ & $0 \%$
\end{tabular}

\begin{tabular}{|c|c|c|c|c|}
\hline \multirow{2}{*}{$\begin{array}{l}\text { Fíbula } \\
(\mathrm{N}=36)\end{array}$} & \multicolumn{2}{|c|}{ Proximal } & \multicolumn{2}{|l|}{ Distal } \\
\hline & $\begin{array}{c}n^{\circ} \text { de ossos com artrose } \\
/ N^{\circ} \text { observáveis }\end{array}$ & Percentagem & $\begin{array}{c}n^{\circ} \text { de ossos com artrose } \\
/ N^{\circ} \text { observáveis }\end{array}$ & Percentagem \\
\hline Indeterminados & $0 / 1$ & $0 \%$ & $0 / 7$ & $0 \%$ \\
\hline
\end{tabular}

\begin{tabular}{|c|c|c|} 
Vértebras & $n^{\circ}$ de ossos com artrose / $N^{\circ}$ observáveis & Percentagem \\
\cline { 2 - 3 }$(\mathrm{N}=39)$ & $6 / 39$ & $15.4 \%$
\end{tabular}

$O$ facto de as lesões degenerativas serem relativamente mais frequentes na coluna vertebral, nomeadamente ao nível dos corpos vertebrais $(10)$, é um dado comum. Efectivamente, mesmo nas populações actuais, a partir dos 30-35 anos, é normal aparecerem lesões degenerativas na coluna, lesões essas que tendem a anteceder as do esqueleto apendicular. Por outro lado, se atendermos à fraca expressividade das lesões artrogénicas, que nunca são severas, torna-se evidente que a amostra analisada não incluiria indivíduos de idade mais avançada (>50 anos).

A observação das patologias degenerativas não articulares (entesopatias) sofreu o mesmo tipo de constrangimentos. Na tíbia apenas foram detectadas

(10). Discartrose, já que a verdadeira artrose das articulações interapofisárias não foi possivel de observar, devido à inexistência dos processos posteriores das vértebras. 
entesopatias na linha solear ( $18.8 \%$ e $28 \%$, no lado esquerdo e direito, respectivamente). Os fémures apresentam entesopatias na linea aspera (1.9\% e $1.7 \%$, esquerdos e direitos); no grande trocanter (6.6\% e $12.5 \%$ ) e na fossa digital ( $12.5 \%$ e $8.3 \%)$. Quanto aos úmeros, apenas se observaram lesões nas inserções musculares da epitróclea esquerda (20\%), da crista lateral supracondilar (5.8\% e 10.9\%) e na inserção deltóide (13.3\% e 10\%). As fibulas apresentam $25 \%$ de lesões entesopáticas no maléolo lateral e 42\% no ligamento tíbio-fibular.

Os rádios e os cúbitos, mais uma vez, não apresentam qualquer tipo de lesão degenierativa não articular. Concluiu-se, assim, que são os membros inferiores os mais afectados pelas entesopatias, o que significa que terão sido estes membros os mais requisitados ao nível do esforço muscular.

Registaram-se outras observações, frequentes, que estão igualmente correlacionadas com o esforço físico. Trata-se de defeitos corticais benignos, que se assemelham a depressões alongadas, com margens corticais lisas, com o interior irregular e por vezes mesmo poroso. Estes podem ser interpretados como uma resposta ao constrangimento físico excessivo localizado na inserção dos músculos pectoralis major e teres major (na região proximal do úmero). Estes músculos são responsáveis pela extensão do braço para baixo, assistindo na adução e rotação medial do braço (como, por exemplo, no movimento de escavar, OWSLEY et al., 1991, passim). Este defeito cortical também é frequente na região da linha solear da tíbia, um local de inserção do músculo solear (soleus), responsável pelo levantar do calcanhar e flexão plantar do pé (movimento frequente quando se anda a pé ou a cavalo).

Atendendo a que a presente série se reporta a combatentes, ainda que, na sua maioria, não profissionais, tornou-se lógica a pesquisa de sinais que evidenciassem isso mesmo. No campo das lesões nas zonas de inserção muscular, está descrito um conjunto de lesões que, associadas, permitem 164 identificar um cavaleiro. Trata-se da denominada Síndrome de Covaleiro (PÁLFI e DUTOUR, 1995, passim). No entanto, a identificação de um "cavaleiro" implica a existência de esqueletos completos, o que não é o caso. Consequentemente, a pesquisa centrou-se na observação de zonas esqueléticas isoladas, como a tuberosidade isquiática, a cabeça femoral, entre outros indicadores dessa síndrome. Dos resultados obtidos, destaca-se o facto de, em 188 regiões proximais do fémur, 38 (20.2\%) apresentarem 
desenvolvimento dos músculos gluteus medius e maximus. Mais ainda, em 88 fémures com a região distal preservada, 44 (50\%), apresentavam desenvolvimento dos músculos gastrocnemius lateral e medial. Logo, poderemos aventar a hipótese de uma percentagem significativa de fémures corresponderem a indivíduos que tenham montado a cavalo frequentemente. Por outro lado, há diversas referências nas fontes escritas à presença de muitos cavaleiros na batalha de Aljubarrota, facto que também pode ser corroborado pelos ossos da fauna recuperados juntamente com os restos humanos, ossos esses que tudo indica tratarem-se de cavalos (PAÇO, 1962, p. 121$)$.

\subsubsection{Patologia infecciosa}

A patologia infecciosa era, na época medieval, uma das doenças mais mortíferas. Este fenómeno devia-se essencialmente a uma baixa esperança média de vida (que diminuía a prevalência de doenças coronárias e degenerativas) e à inexistência de um eficaz combate médico às infecções (ROBERTS E MANCHESTER, 1995, p. 124).

O estudo da patologia infecciosa é complexo, já que existem inúmeros factores que são interactuantes na sua prevalência, como por exemplo a dieta (sendo a má nutrição um factor que predispõe a doenças infecciosas), o nivel social, o ambiente, a densidade populacional, as condições de higiene, as condições imunológicas (como a resistência do hospedeiro), etc (CUNHA, 1994, passim). Porém, é simultaneamente um estudo compensador, na medida em que, devido aos diversos factores que a integram, é particularmente útil na reconstrução do quotidiano das populações analisadas.

Na presente amostra, só foram detectadas lesões infecciosas não específicas, ou seja, alterações causadas por agentes patogénicos vários e não identificados. As manifestações ósseas de infecções são comuns no material osteoarqueológico e fornecem boas evidências de uma resposta a agressões exógenas ao osso (in vivo). Porém, apesar das boas pistas que fornecem, não nos conduzem ao diagnóstico desejado, porque em geral não são associáveis a um agente agressor específico (CUNHA, 1994, passim). 
A elevada incidência de patologia infecciosa não activa e remodelada (24.7\% - 87/352) traduz uma resposta inflamatória do periósteo (camada mais superficial do osso) a episódios de stresse, agudos ou crónicos. Por outras palavras, todas as lesões infecciosas observadas reportam-se a lesões antigas, não contraídas na batalha, e resultantes de agressões traumáticas, microbianas ou outras (PÁLFI, 1997, p. 56).

A alta frequência deste tipo de lesões não pode, no entanto, ser considerada surpreendente: estamos perante um grupo de homens que poderão já ter intervindo noutras batalhas. Assim como, mais provavelmente, tratar-se-á de uma amostra do povo comum, com as mais variadas profissões, que terão sido recrutados para esta batalha.

De estranhar será a quase completa inexistência (apenas um caso observado - Fig.3.15) de lesões infecciosas activas na altura da morte. $\mathrm{Na}$

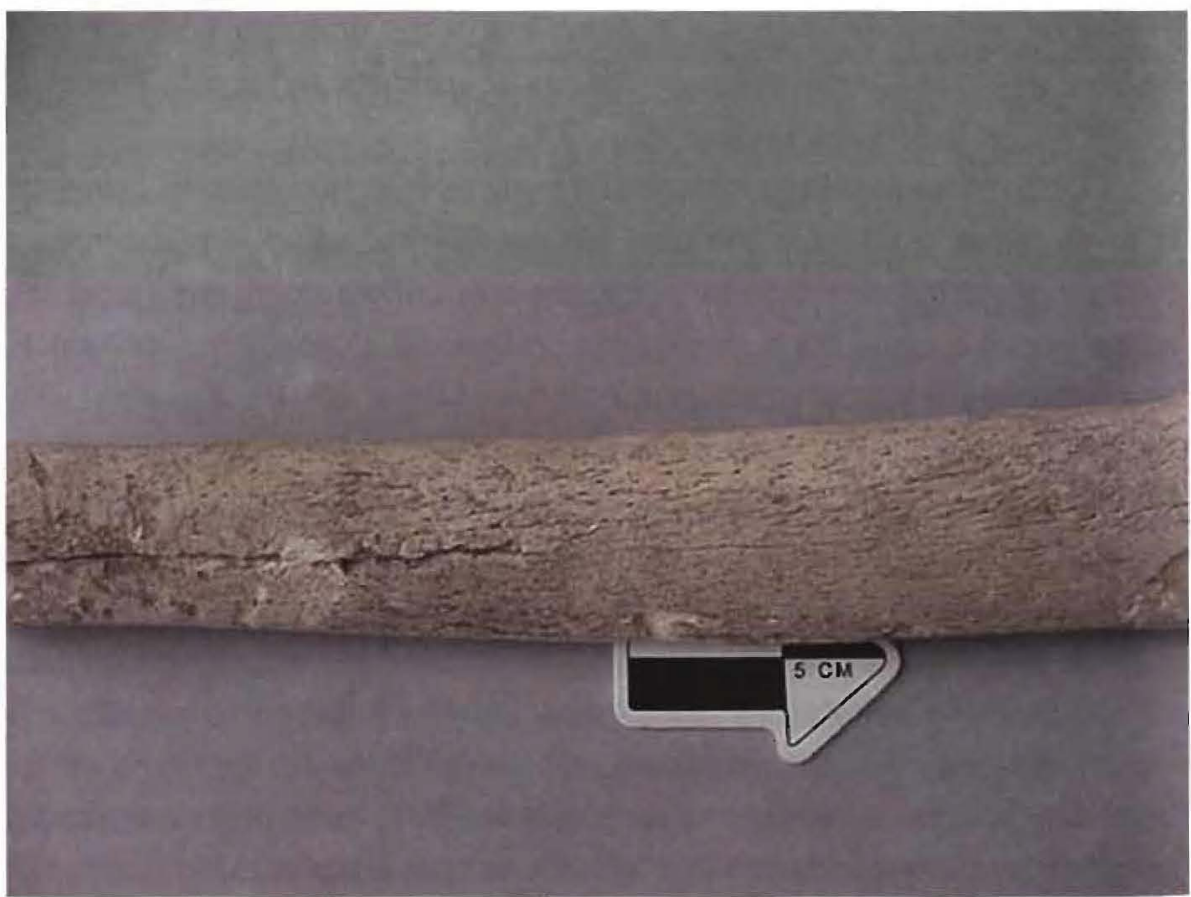

Fig. 3.14 - Tíbia com periostite remodelada. 
fig. 3.15 é visível uma placa de osso novo, sinal característico das infecções activas. Talvez as fortes alterações tafonómicas sofridas pela série osteológica constituam a causa mais provável de tão baixa frequência destas lesões. Contudo, todo o tipo de ilações que possamos retirar desta constatação carecem de verificação. Ou seja, será que os indivíduos com patologias infecciosas activas não entraram no combate? Parece-nos pouco verosímil.

Detectámos também casos particulares de infeç̧ões decorrentes de complicações na cura de fracturas. É sabido que as fracturas expostas são propensas a um desenvolvimento de infecções, facilitando a entrada de qualquer agente patogénico no local da fractura, causando danos. Na série de Aljubarrota, este tipo de infeç̧ão pós-traumática é frequente, sendo indiciado pelas marcas de calo ósseo e periostite remodelada num mesmo local. As deficientes condições de higiene e um tratamento médico inadequado podem estar correlacionados com a elevada incidência destas complicações.

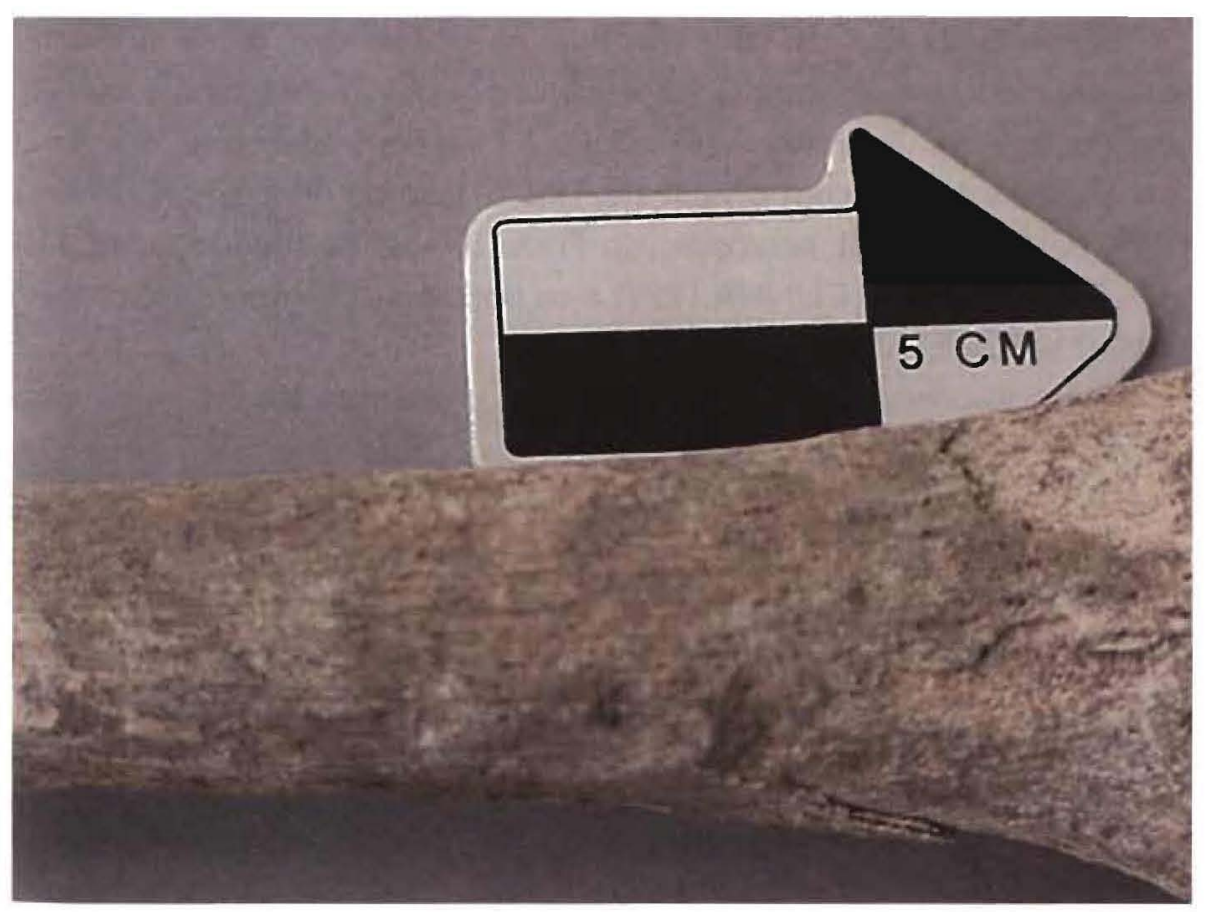

Fig. 3.15 - Periostite activa numa tíbia. 


\subsubsection{Patologia oral}

Podemos recorrer aos dentes como testemunhos de hábitos culturais e quotidianos, visto que estes incorporam uma grande variedade de características, que reflectem o que "foi colocado na boca" (GOODMAN e ROSE, 1991, passim). Consequentemente, a sua óptima preservação em contextos arqueológicos confere-lhe um papel central nos estudos da paleobiologia (CUNHA, 1996, passim).

Do ponto de vista metodológico, as cáries foram classificadas em termos de tamanho e local de origem segundo as escalas de LUKACS (1989) e MOORE e CORBERT (197I) (in LARSEN,199I, passim). O desgaste foi avaliado pela escala de SMITH (1984). O tártaro foi registado de acordo com a escala de MARTIN e SALLER, 1956 (in HILLSON, 1996, passim).

Resultados da patologia oral

A percentagem de cáries obtida, na ordem dos $8 \%$, é um valor consentâneo com os resultados verificados noutras populações ibéricas coevas (que variam entre os 3 e os 12.3\%.), nomeadamente nas séries portuguesas de Fão, com o valor de 4.8\%, S. João de Almedina (Coimbra), 8.9\% (CUNHA, 1994), necrópole do Prazo (Freixo de Numão) com 11\% de cáries (MATOS e CUNHA, 1999) e na população de Maiorca (Coimbra) 10\% (MARQUES, 2000).

Estes valores de cáries poderão estar correlacionados com uma dieta rica em carbohidratos, que não eram removidos da superfície dos dentes.

A baixa incidência de desgaste, com um valor médio de 2.5 (na escala de 0 a 8 de SMITH, 1984, passim), a escassa percentagem de perda de dentes ante-mortem (5.2\%), aliado ao tártaro vestigial e a poucos indícios de doença

168 periodontal, mesmo atendendo à fraca representatividade do $n^{\circ}$ total da amostra de dentes relativamente ao efectivo da série, não podem ser considerados como indicadores fidedignos dos hábitos de higiene oral ou do tipo de alimentação predominante( ${ }^{(I I)}$. Acrescente-se que a perda de

(II). Resultados que poderiam ser obtidos por uma análise de paleodietas. 
dentes post mortem atinge $60 \%$, o que reforça a subestimação dos referidos parâmetros.

\subsubsection{Indicadores de stresse}

Os indicadores de stresse do esqueleto referem-se a um conjunto de elementos pesquisáveis, que nos informam acerca dos períodos de desequilibrio entre 0 indivíduo e o meio ambiente durante o crescimento (CUNHA, 1994, passim). Os indicadores de stresse funcionam como delatores de uma resposta fisiológica resultante da luta de um organismo e/ou população em se adaptar, isto é, são uma consequência de eventos disruptivos que actuam sobre o organismo. Esta resposta culmina, nomeadamente, em alterações permanentes a nível dos dentes, ou dos ossos longos.

As hipoplasias lineares do esmalte dentário (indicador de stresse episódico) revelaram-se inexistentes. Mais uma vez, a má preservação do material, neste caso dos dentes, em especial dos anteriores, mais propensos à queda ante-mortem, não permite concluir se a ausência é de facto verdadeira.

Resultados dos indicadores de stresse

$\mathrm{Na}$ análise radiológica das tíbias, destacamos algumas linhas de Harris, testemunhos de períodos de distúrbio fisiológico na infância e adolescência algo conturbados. A quantificação exacta destas linhas (sinónimo de perturbações no crescimento) não é possível devido, invariavelmente, à má preservação das tíbias.

Foram identificados alguns casos de cribra orbitalia, pequenas porosidades no tecto das órbitas, que têm vindo a ser relacionadas com anemia (24 casos em 42 órbitas pesquisáveis: 57\%). No entanto, só uma confirmação por análise histológica poderia certificar a etiologia precisa destas lesões.

Também foi detectada alguma porosidade craniana associada a remodelação de Hiperostose Porótica (HP). A maioria dos autores, na contemporaneidade, sugerem uma abordagem multifactorial do problema, 
considerando que a HP é o resultado de uma interacção entre os costumes das populações, as dietas pobres em ferro, os hábitos de higiene e um incremento temporal de doenças virais, bacterianas e parasíticas, trazidas por um maior sedentarismo e uma maior densidade populacional (CUNHA, 1994). Por este motivo, muitos investigadores têm recorrido à HP como uma ferramenta na investigação da saúde e do estado nutricional das populações do passado. À semelhança da cribra orbitalia, a qual pode mesmo ser considerada como um tipo de HP, o agente causador das lesões da HP só poderá ser confirmado através de análise histológica (WAPLER, 1998).

\subsubsection{Casos particulares}

Neste sub-capítulo são apresentadas lesões particulares que justificam uma descrição isolada.

Perfurações

Na pesquisa das perfurações detectou-se uma diáfise de fémur com vestígios do que considerámos ser um fragmento de metal na região proximal e posterior, ou seja, ligeiramente abaixo do pequeno trocânter. $O$ metal apresentava todas as evidências de ter sido impactado no osso na altura da morte do indivíduo (peri-mortem). Consequentemente, justificava-se a sua análise química detalhada, pelo que a amostra foi enviada para o Instituto Tecnológico e Nuclear (ITN) em Sacavém. A análise visava confirmar se se tratava de metal e, nesse caso, qual a sua composição. Os resultados da pesquisa no ITN revelaram que se tratava efectivamente de metal, maioritariamente Ferro (cf. documento em anexo: 3).

Um pequeno fragmento craniano, que não foi possível de identificar, apresentava, tal como no caso anteriormente descrito, um fragmento de metal impregnado no osso. Não obstante não ter sido feita a análise química deste osso, tudo leva a crer que se tratava do mesmo tipo de metal.

A confirmação da existência de metal embutido no osso permite afirmar que projécteis tais como setas ou virotões foram usados na batalha. A não 
deteç̧ão de quaisquer evidências de remodelação óssea nas áreas imediatamente adjacentes à que continha o metal, implica que a lesão infligida terá (em ambos os casos) ocorrido na altura da morte.

\section{Hematomas}

Este tipo de lesões revelou-se particularmente frequente em Aljubarrota. Trata-se de um outro tipo de complicação pós-traumática. Na sequência de um episódio traumático, se for exercido um stresse excessivo a nível do périosteo, a reabsorção do hematoma é impedida. Nestes casos, produzse, ao longo de aproximadamente 2 meses após a lesão, uma pequena massa óssea, cuja calcificação é também visível radiologicamente (LOVELL, 1997, pp. 139). No espólio de Aljubarrota, este tipo de lesões prevalece nos fémures e nas tíbias (Figs. 3.16a e 3.16b)

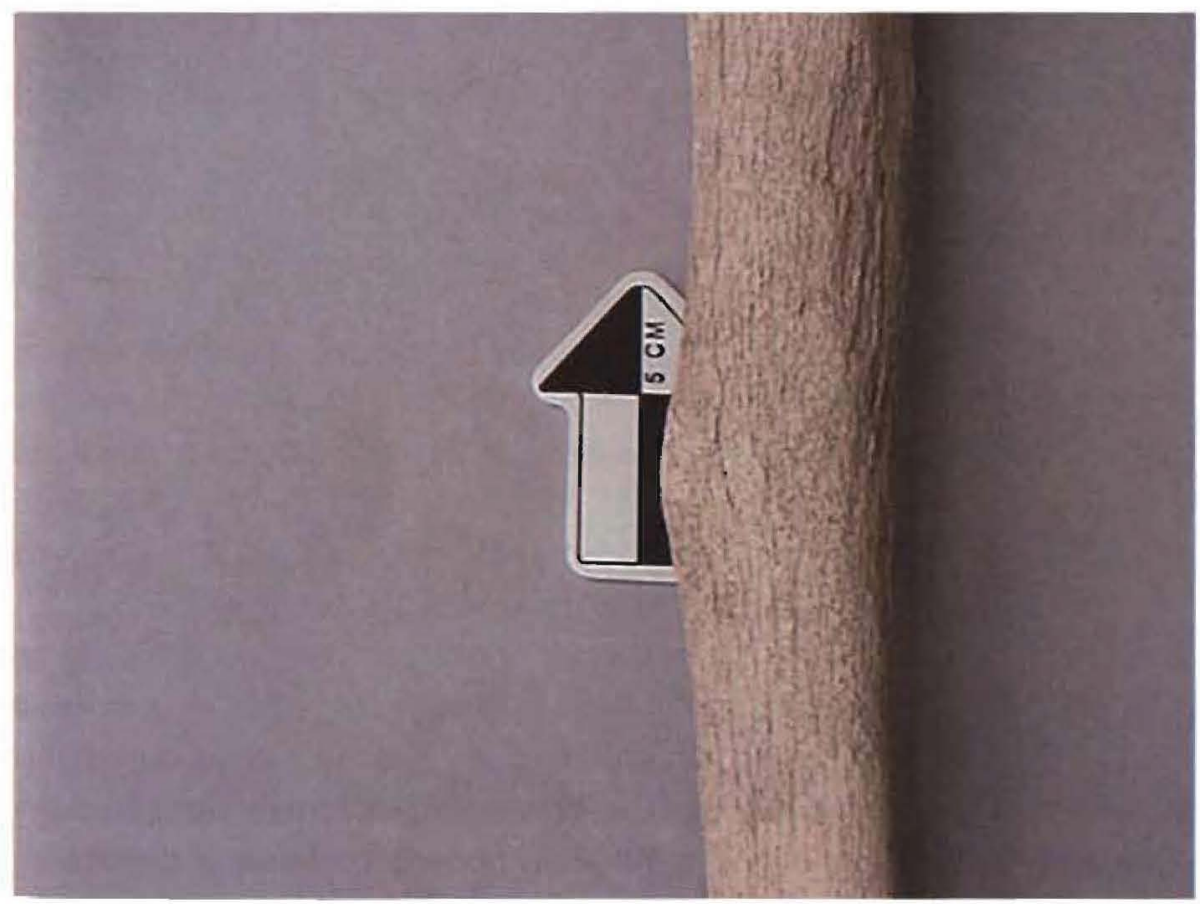

Fig. 3.16a - Calcificações consequentes de hematomas não absorvidos, na diáfise de tíbia. 


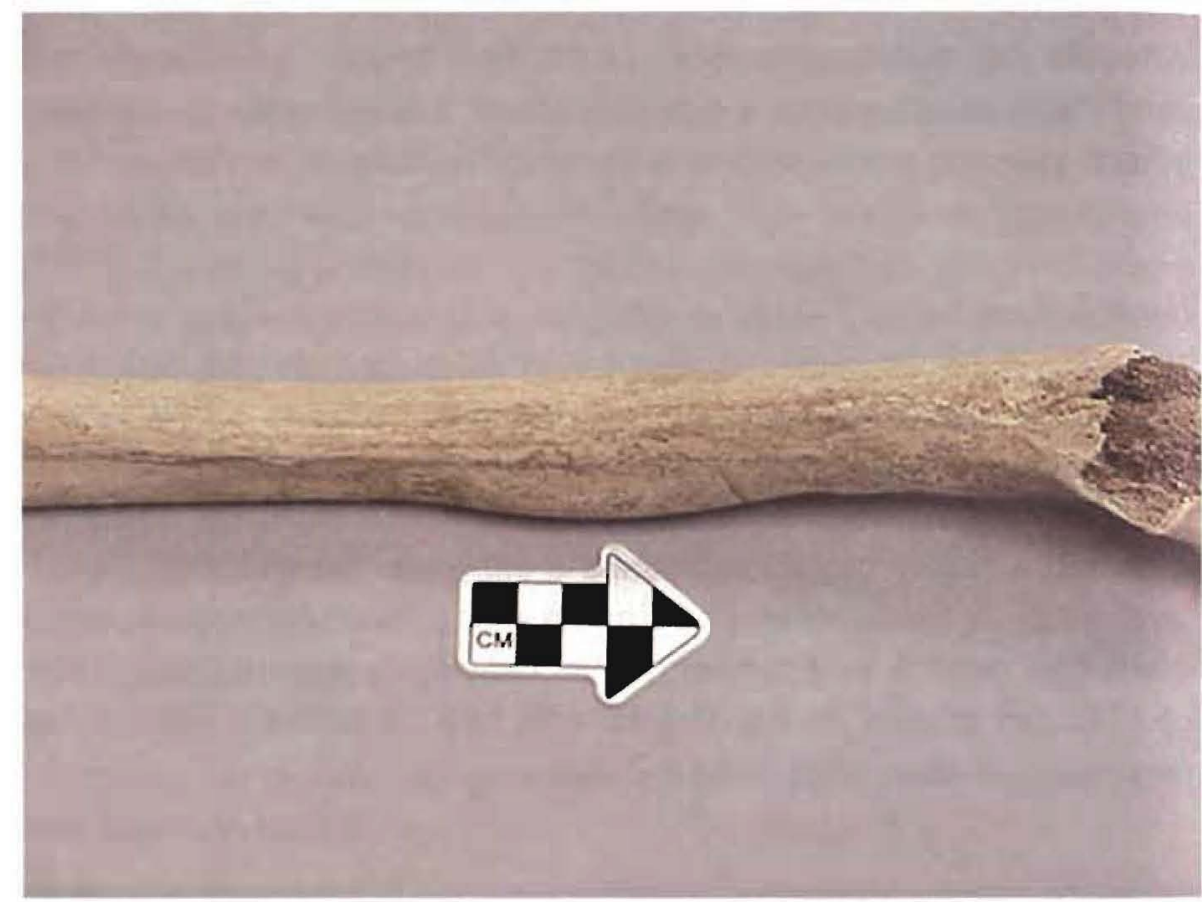

Fig. 3.16b - Calcificações consequentes de hematomas não absorvidos, na diáfise de fémur.

\section{Fusão do calcâneo com talus}

Detectou-se uma fusão completa entre o talus e o calcâneo direitos (ossos do pé) (Fig. 3.17). A análise radiológica não revelou qualquer linha de fractura. Consequentemente, a hipótese de se tratar de um caso de fusão congénito talo-calcaneal foi reforçada. Não obstante, e atendendo ao facto de as linhas de fracturas antigas poderem ser reabsorvidas, a hipótese de se tratar de um caso traumático não pode ser totalmente descartada.

172 Esta fusão talo-calcaneal adquire um relevo particular no contexto de uma série osteoarqueológica de batalha. Questões tais como a de saber o que faria um indivíduo com uma lesão deste tipo no campo de batalha parecem pertinentes. Com efeito, este tipo de alteração patológica afectaria a locomoção. Se é certo que o indivíduo poderia continuar a deslocar-se pelos seus próprios meios, é igualmente certo que não teria a agilidade, nomeadamente ao nível do tornozelo, de uma pessoa normal. 


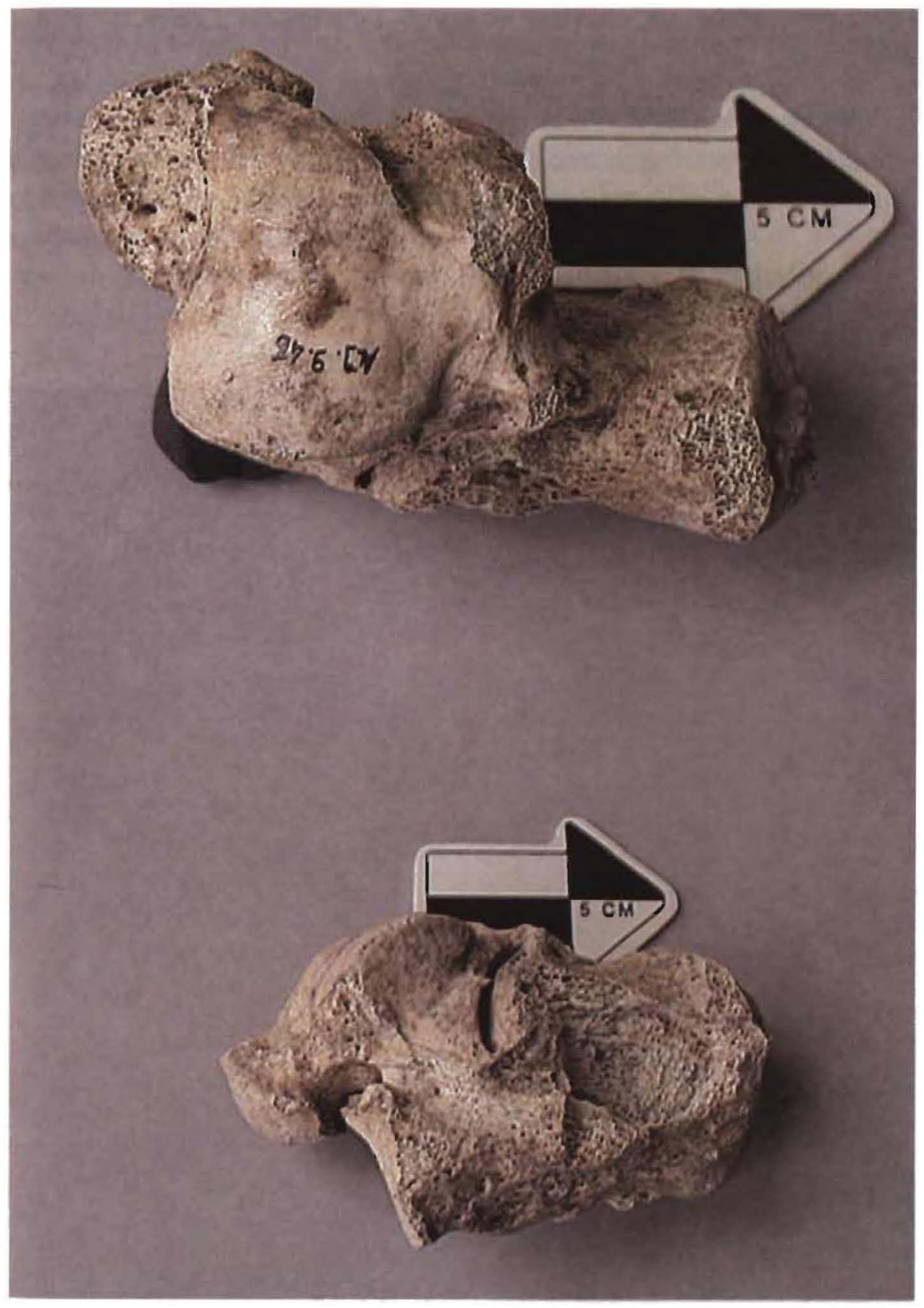

Fig. 3.17 - Fusão talo-calcaneal direita em posição anatómica e em vista medial. 
Fracturas particulares

Vale a pena destacar uma fractura ao nível do terço distal do úmero (Fig. 3.9a). A grande deformação sofrida por este osso permite afirmar que se trata de uma lesão mal curada. Ou seja, a imobilização do osso terá sido mal feita, ou não terá sequer tido lugar, o que levou a que o osso se voltasse a unir de um modo desajustado. Este trauma, que relembramos não ter sido

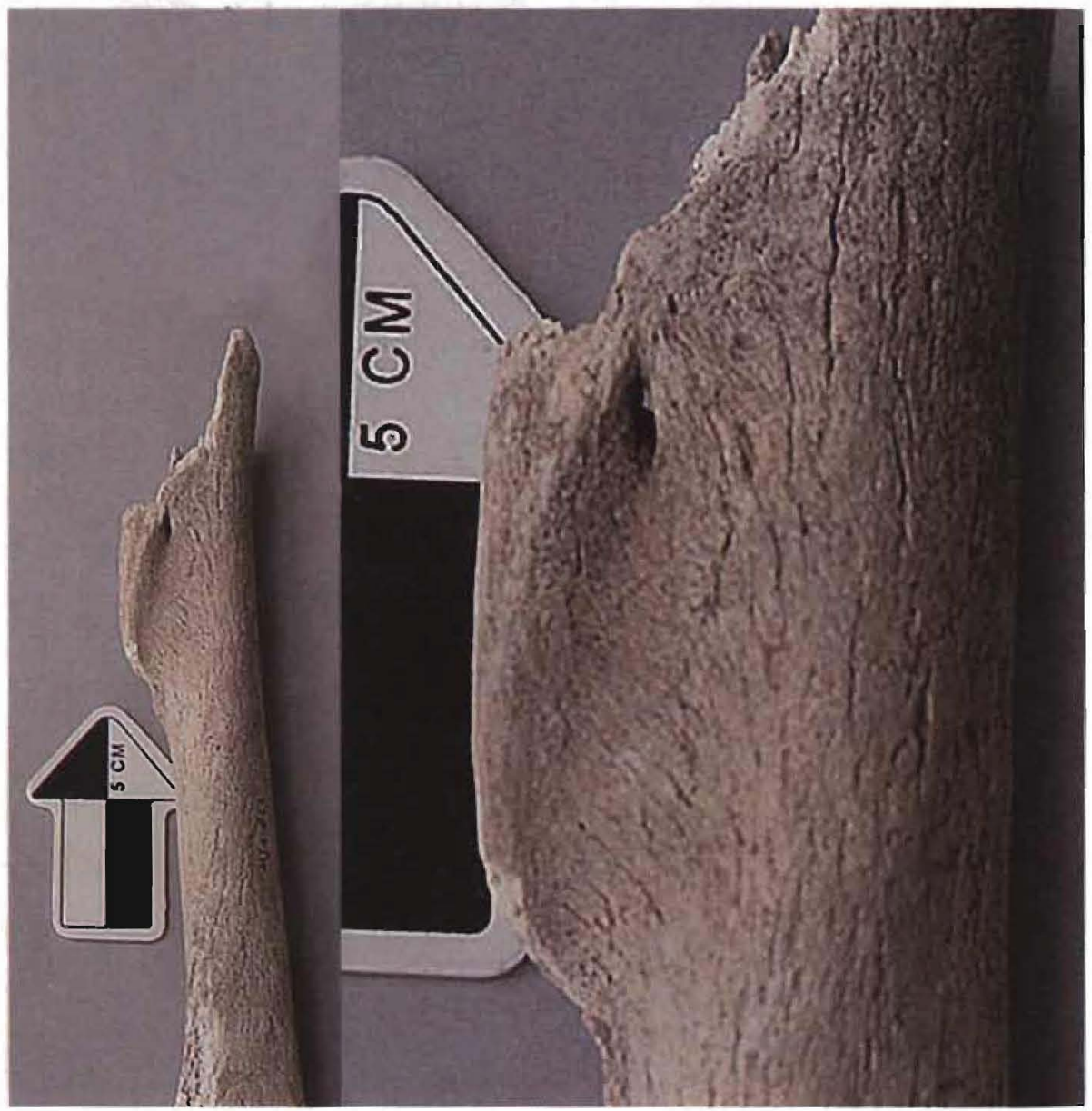

Fig. 3.18 - Úmero com lesão traumática. Apresenta-se o pormenor da lesão. 
contraído na batalha em causa (trata-se de uma lesão remodelada), poderá ter resultado de uma agressão directa penetrante, ou ainda de uma queda, ou de uma fractura indirecta (oblíqua ou em espiral). Uma vez mais, a mobilidade do membro superior esquerdo deste indivíduo estaria bastante reduzida, sendo também provável que existissem lesões de artrose secundárias ao processo traumático.

Um outro exemplo de uma remodelação incorrecta é visível na fig. 3.18. O que parece ter acontecido é que após um corte, ou uma fractura, a porção de osso que se separou da diáfise não se reintegrou normalmente.

Outro caso relevante reporta-se a um fémur esquerdo, o qual, na superfície lateral da sua diáfise, apresenta uma depressão lisa e oval $(4 \mathrm{~cm}$ $\times 2 \mathrm{~cm}$ ), que terá sido produzida pouco tempo antes da morte do indivíduo. A forma do trauma sugere que terá sido uma perna a ser atingida por um corte de uma espada (Fig. 3.19).

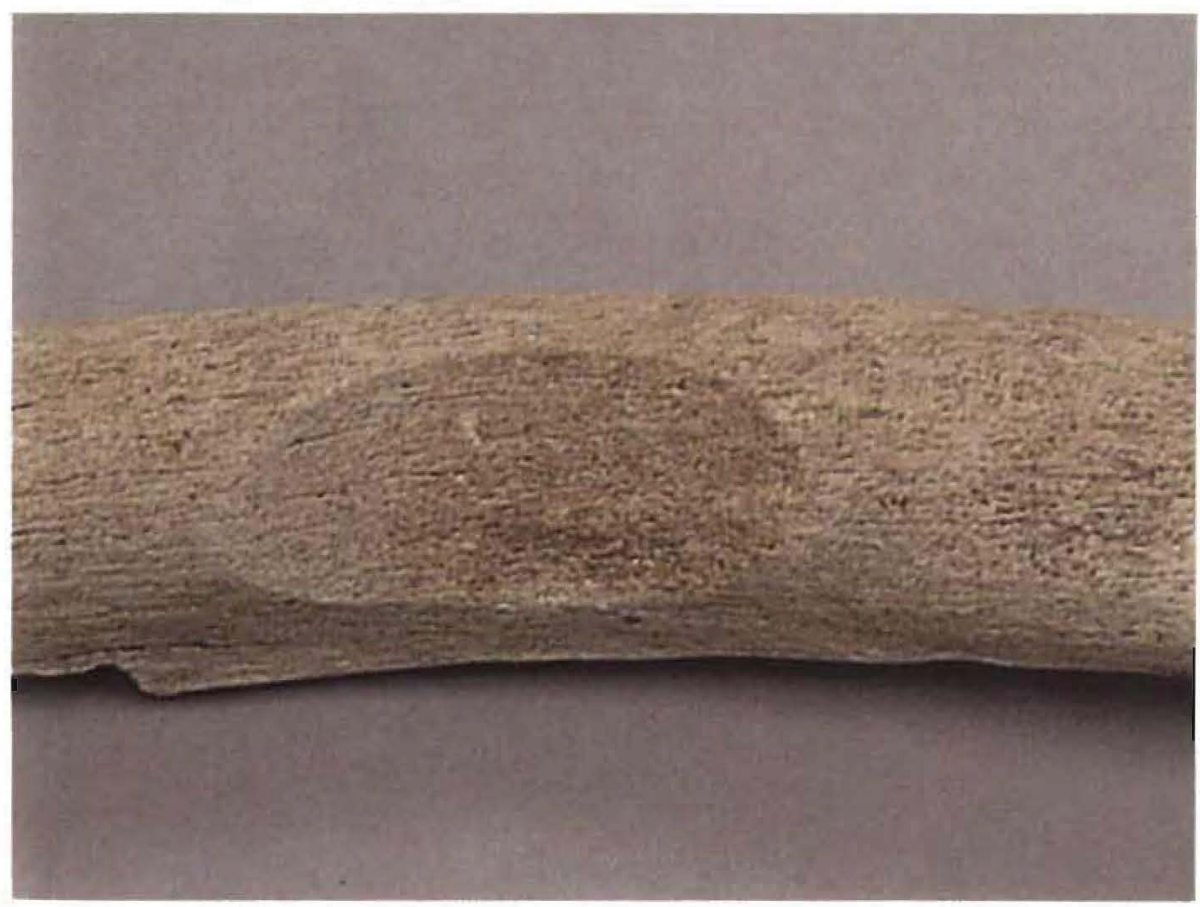

Fig. 3.19 - Fémur com lesão produzida por objecto cortante. 
Apenas foi detectado um caso de deslocamento. Apesar de estarmos na presença de um ossário (ossos desarticulados e em isolado) o deslocamento foi testemunhado pela existência de uma pseudo-articulação numa extremidade distal de um úmero, o que sugere que uma agressão externa terá produzido um deslocamento parcial (ou subluxação) e uma consequente má articulação do úmero com o cúbito adjacente, que passou a articular num outro local mais medial. Este episódio terá ocorrido bastante tempo antes da morte, já que a formação da nova articulação estava bastante bem definida, apresentando patologia degenerativa secundária a este evento, num grau extremo (eburnação, Fig. 3.20).

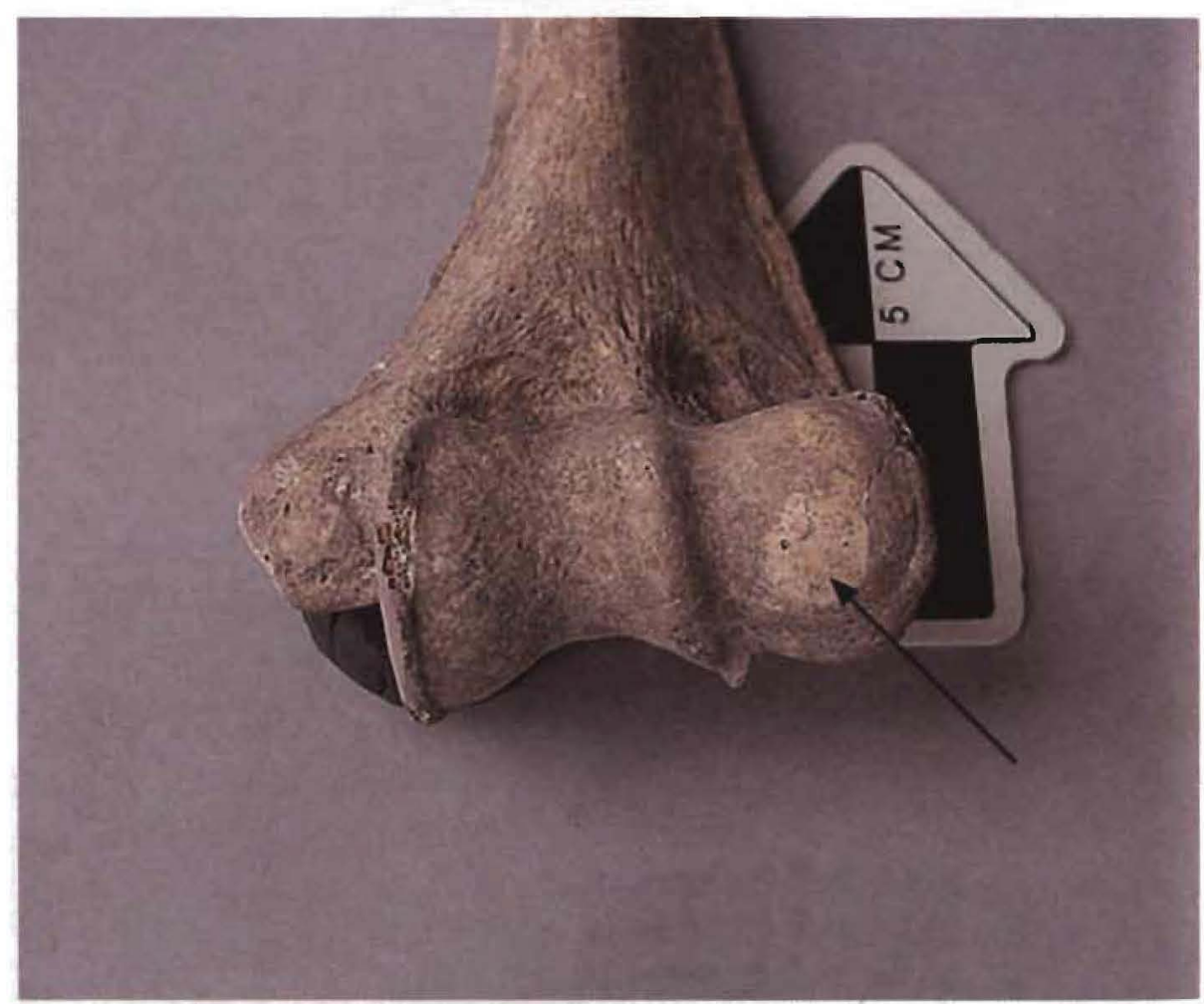

Fig. 3.20 - Úmero esquerdo com eburnação. 
Um outro caso refere-se a um fragmento de diáfise de úmero direito, com cerca de $15 \mathrm{~cm}$ de comprimento, que apresenta uma série de alterações intrigantes. Na sua extremidade distal há indícios de ter havido um corte transversal, que poderá ter removido a parte inferior do braço. Há, no entanto, dificuldades, devido às lesões tafonómicas, em interpretar a zona do corte. A zona em causa parece-nos remodelada e, aparentemente, lisa, o que sugere de imediato, uma amputação. No entanto, não se observa formação de osso novo, o que levanta algumas dúvidas no diagnóstico etiológico. Ou seja, se por um lado não é, definitivamente, um caso de amputação peri-mortem, por outro, não é também um caso típico de amputação antiga. Resta apenas a hipótese de se tratar de um corte violento, ocorrido algum tempo antes desta batalha. Mais uma vez, estaremos perante um caso de um indivíduo sem o uso pleno das suas capacidades físicas a combater (a menos que se tratasse de um auxiliar, não combatente). Acrescente-se que o possivel corte terá sido infligido quando o indivíduo teria o braço levantado, em posição de defesa. Finalmente é também possivel que a lesão tivesse sido provocada por esmagamento (Fig. 3.21).

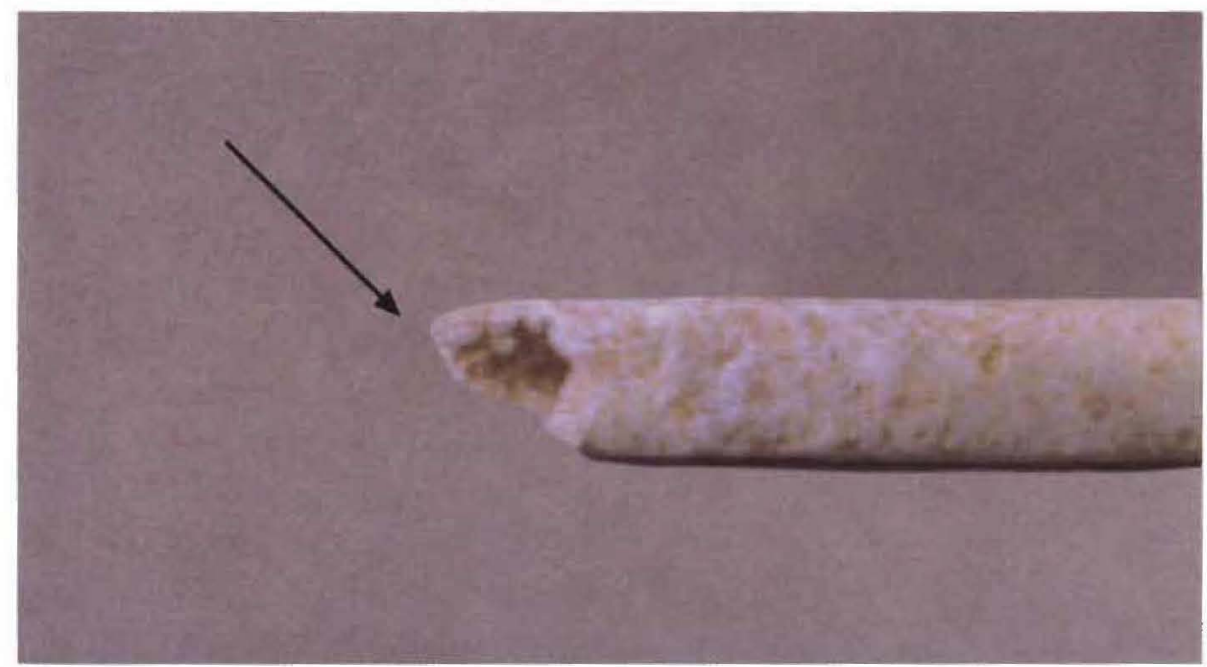

Fig. 3.21 - Úmero com possível amputação. 
A hiperostose frontalis interna, patologia relativamente rara, é uma forma particular de crescimento ósseo na tábula interna do frontal, devido a uma desordem no endocrânio, que remodela numa forma diferente dos outros ossos do crânio (HERSHKOVITZ et al., 1999). A lesão inicial foi detectada num frontal e corresponderia a uma fase inicial da doença, já que apenas eram visíveis pequenas ilhas múltiplas e isoladas de osso, com início de formação de nódulos pouco elevados (Fig. 3.22).

Sabe-se quie é mais comum nas mulheres, mas o fenómeno já foi observado em homens. A sua etiologia é bastante incerta, porém, estudos recentes apontam para a possibilidade de este fenómeno ser despoletado por distúrbios nas gónadas, com alterações dos níveis de estrogénio e de testosterona. No caso dos homens, a doença pode culminar com uma atrofia dos testículos (HERSHKOVITZ et al., 1999).

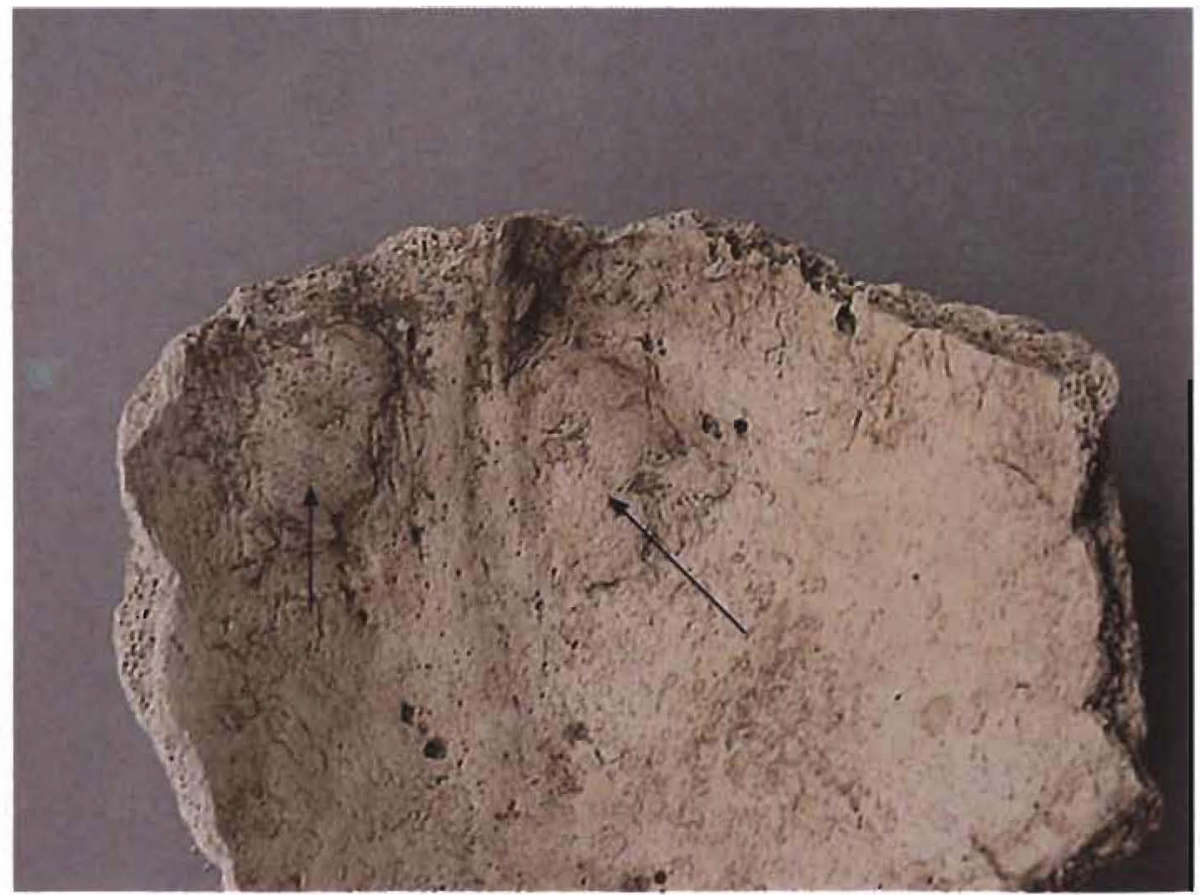

Fig. 3.22 - Crânio com lesões internas associadas à Hiperostose Frontalis Interna. 


\subsection{Conhecimentos médicos no século XIV}

Uma das informações mais curiosas que a série osteoarqueológica em apreço permite obter ultrapassa, claramente, o âmbito da batalha de Aljubarrota. Trata-se do tipo de conhecimentos médicos disponíveis na sociedade medieval dos finais do século XIV. Efectivamente, algumas das muitas lesões remodeladas indiciam uma intervenção médica. Reporta-se aqui um dos casos mais relevantes.

Trata-se de um frontal que terá sofrido um golpe de dimensões consideráveis, tanto ao nível da extensão da lesão, como da profundidade da mesma. O golpe terá aberto um buraco no crânio. Na tentativa de tratar a lesão, terá havido uma intervenção "médica", a qual é sugerida por dois pequenos orifícios. Reportando-se o crânio em questão ao século XIV, e tratando-se de uma lesão que indica que o indivíduo sobreviveu à intervenção, estamos perante um caso, porventura único em todo o espólio desta batalha, de uma prática médica bem sucedida.

\subsection{Comentários finais}

O estudo paleobiológico da série de Aljubarrota permitiu, não só confirmar várias suposições, como também fornecer novos dados sobre os combatentes de Aljubarrota. Assim, o quantitativo de indivíduos detectados, juntamente com a ausência de mulheres e ainda a frequência e tipo de lesões traumáticas, são claramente indicativos de se tratar de uma série de um contexto de batalha. Por outras palavras, se dúvidas houvesse sobre a proveniência exacta desta série depositada no Museu Antropológico da Universidade de Coimbra há cerca de 40 anos, essas dúvidas foram dissipadas definitivamente. Por outro lado, também a datação por ${ }^{14} \mathrm{C}$ obtida conferiu mais certeza à proveniência do espólio osteológico. Outro dado importante a retirar deste estudo é que o próprio estado de fragmentação e as alterações tafonómicas dos ossos estão de acordo com as fontes documentais, que referem um abandono dos corpos no campo de batalha por um período de tempo considerável.

Relativamente aos dados novos inferidos a partir do estudo dos ossos, talvez a informação mais relevante seja a que se reporta à patologia 
traumática. $\bigcirc$ estudo detalhado deste tipo de lesões sugeriu um cenário de batalha em que as notas dominantes eram simultaneamente a violência e um certa confusão. Igualmente importante foi a detecção de lesões traumáticas maioritariamente cicatrizadas, ou seja, não decorrentes da batalha em causa e, também, reaç̧ões ósseas infecciosas igualmente remodeladas. Não obstante, foram ainda assim encontradas algumas lesões que deverão, muito provavelmente, ter provocado a morte no campo de batalha. Referimo-nos aos cortes e às perfurações.

As incidências das lesões traumáticas detectadas poderão adquirir um maior significado se comparadas com a frequência deste tipo de lesões em populações "naturais" (12) coevas. Uma ambição que, como é evidente, não ignora o facto de os esforços comparativos serem perturbados pela dificuldade em calcular frequências credíveis para séries coevas das que constituem o objecto de estudo. Já ROBERTS (1991), na sua tentativa de sistematização das lesões traumáticas nas populações do passado, chamou a atenção para este e para outros problemas inerentes aos estudos comparativos de incidências paleopatológicas. $O$ facto do estado de conservação dos esqueletos ser extremamente variável, torna muito difícil concretizar comparações fidedignas. Nas muitas publicações sobre estudos paleobiológicos de séries medievais ibéricas (ver, por exemplo, CUNHA e CRUBÉZY, 2000), as frequências exactas dos vários tipos de lesões traumáticas nunca são apresentadas: há descrições dos casos traumáticos mais relevantes (permitindo aferir do maior ou menor grau de raridade dos cortes e incisões); são também citados os casos de trepanações e outros (permitindo elucidar sobre os conhecimentos médicos da época); mas nunca são referidas as incidências exactas por tipo de osso, procedimento que, tendo sido levado a cabo no caso de Aljubarrota, carece assim da desejada confrontação.

Ainda assim, achámos útil facultar alguns valores comparativos. Uma das 180 séries escolhidas para comparação foi a medieval de S. João de Almedina

(12). Entende-se por população "natural" aquela que é constituída por uma proporção equilibrada de indivíduos de ambos os sexos e de todos os grupos etários. A série aqui analisada, a de Aljubarrota, é claramente o oposto. Trata-se de um série dita seleccionada, composta apenas por homens. 
(CUNHA, 1994) composta por II 5 indivíduos, maioritariamente adultos, que viveram em Coimbra entre os séculos XII e XV(13).

Trata-se de uma série urbana que inclui vários indivíduos com mais de 50 anos. Apenas umas das lesões - no crânio - terá provocado a morte, o que altera drasticamente a frequência das lesões traumáticas cranianas $(1 / 70=1.42 \%)$ e, simultaneamente, torna mais significativas as frequências detectadas para Aljubarrota. Todas as outras lesões apresentam sinais de remodelação.

Já quando se procede à comparação com uma série medieval rural, como a da Quinta de S. Pedro (Corroios, Seixal, séc. XV, LOPES e CUNHA, 1998), que supostamente inclui muitos trabalhadores rurais, detecta-se uma maior incidência de traumas, mas também eles sempre cicatrizados e claramente relacionados com acidentes inerentes à profissão (LOPES e CUNHA, 1998).

Ou seja, quando se comparam as incidências traumáticas, torna-se evidente que há uma certa especificidade dos traumas, estando os detectados para Aljubarrota claramente relacionados com a violência praticada na batalha. Basta evocar a facilidade com que cortes, incisões ou perfurações são detectados na série osteoarqueológica de Aljubarrota, e o contraste de um tal panorama com o detectado para S. João de Almedina, onde há apenas um caso de uma incisão (no crânio), ou com o do Seixal,

(13). Na tabela seguinte estão indicados os valores encontrados para as lesões traumáticas na série adulta de $\mathrm{S}$. João de Almedina.

Tabela 3.5 - Frequência das lesões traumáticas em S. João de Almedina (CUNHA, 1994).

\begin{tabular}{lc|c} 
Tipo de osso & & \multicolumn{2}{c}{ Percentagem de lesōes traumáticas } \\
\cline { 3 - 3 } Crånio & $7 / 61$ & $(11.4 \%)$ \\
Clavícula & $1 / 50$ & $(2 \%)$ \\
Ulna & $1 / 54$ & $(1.85 \%)$ \\
Rádio & $1 / 48$ & $(2.08 \%)$ \\
Tíbia (luxação) & $3 / 94$ & $(3.2 \%)$ \\
Fémur (luxação & $1 / 111$ & $(0.9 \%)$ \\
\hline
\end{tabular}


onde não há qualquer exemplo desse tipo de trauma, para melhor se entender o alcance da ideia. ${ }^{(14)}$ Ou seja, a determinação do carácter etiológico da lesão, se acidental ou intencional, é determinante para a análise comparativa.

Para finalizar, não queremos deixar de destacar a relevância da série em causa. Trata-se da única série osteológica portuguesa de contexto de batalha e também uma das pouca séries medievais europeias do tipo. Com efeito, conhece-se a série medieval dinamarquea de Naestved (BENNIKE e BARDE, 1999), composta por cerca de 60 esqueletos praticamente completos retirados de uma vala comum (situação completamente distinta da de Aljubarrota, inviabilizando, também aqui, as comparações, na medida em que o tipo de material ósseo preservado em cada um dos sítios é demasiado diverso), a já citada série sueca de Wisby, de onde foram recuperados 1185 esqueletos de guerreiros trecentistas que foram analisados antropologicamente por INGELMARK (1939), ou ainda o espólio osteológico da Batalha de Grunwald, ocorrida em 1410, espólio esse que se encontra em estudo desde 1990 (NADOLSKI, 1990, in CRUBÉZY, 1992). Finalmente, acaba de ser publicada a análise antropológica da Batalha de Towton (Inglaterra), ocorrida em |46| (FIORATTO et al., 2000), cujos resultados esperamos poder comparar com os nossos muito brevemente.

(14). Outros exemplos poderiam ser fornecidos, como o da série medieval do Prazo (Freixo de Numão) (séc. IX-XIII) (MATOS e CUNHA, 1999), em que nenhum dos 45 indivíduos adultos apresenta qualquer trauma. 


\section{Referências Bibliográficas}

BENNIKE, P. ; BRADE, A. E.,

1999 - Middelalerens sygdomme og behandlingsformer / Danmark. Copenhague. Kobenhavns Universitet.

BRUZEK, J.,

1991 - Proposition d'une nouvelle méthode morphologique dans la détermination sexuelle de l'os coxal. Application a la Chaussée-Tirancourt, "Methodes d'etude des sépultures", pp. I 1-20.

CARRETERO, J. M. : LORENZO, C. ; ARSUAGA, J.,

1995 - Análisis multivariante del húmero en la Colección de restos identificados de la Universidad de Coimbra (Portugal), "Antropologia Portuguesa", vol. 13.

CRUBÉZY, E.,

1992 - Le combattant à l'époque médiévale. Vers une approche archéologique et paléopathologique. In: "Le Combattant au Moyen Âge". Sociétes des Historiens Médiévistes de l'Enseignement Supérieur Public, pp. 297-305.

CRUBÉZY, E. ; MORLOCK, G. ; ZAMMIT, J.

1985 - Diffuse idiopathic skeletal hyperostosis and enthesopathy in mediaeval hyperostosis, "Clinical Rheumatology", vol. 5, n. ${ }^{\circ}$ 2, pp.15-16.

CUNHA, E. ; CRUBÉZY, E.,

2000 - Comparative biology of the medieval populations ( $9^{\text {th }} .15^{\text {th }}$ centuries) of the Iberian Peninsula and Southwest of France: Problematics and perspectives. "Journal of Iberian Archaeology", vol. 2, pp.145-164.

CUNHA, E.

1994 - Paleobiologia das Populações Medievais Portuguesas: Os casos de Fão e S. joão de Almedina, Tese de Doutoramento. FCTUC.

CUNHA, E.,

1999 - Paleobiologia, História e quotidiano: critérios da transdisciplinaridade possivel

"Estudos Medievais". Universidade Nova de Lisboa. (No prelo).

CUNHA, E. ; SILVA, A. M.,

1997 - War lesions from the famous Portuguese Medieval Battle of Aljubarrota. "International Journal of Osteoarchaeology", vol. 7. pp. 595-599.

CUNHA, E. : UMBELINO, C.,

1995 - What bones can tell us about labour and occupations? "Antropologia Portuguesa," vol. 13, pp. 49-68. 
FEREMBACH, D. ; SCHWIDETZKY ,1. ; STLOUKAL, M.,

1980 - Recommendations for age and Sex diagnoses of skeleton, "Journal of Human Evolution," vol. 9, n. ${ }^{\circ}$ 7, pp. 517-550.

FIORATO, V. ; BOYLSTON, A. ; KNUSEL, C.,

2000 - Blood Red Roses. The archaeology of a Mass Grave from the Battle of Towton $A D$ 1461. London. Oxbow Books.

GALLOWAY, A. W. H. ; JONES, A. M. ; HENRY, T. H. and PARKS, B. O.,

1989 - Decay rates of Human Remains in an Arid Environment. "Journal of Forensic Sciences". 34. pp. 607-616.

GOODMAN, A. ; ROSE, J.,

1991 - Dental Enamel Hypoplasias as Indicators of Nutritional Status, in Kelley, M., Larsen, C., (eds), 1991. "Advances in Dental Anthropology", Wiley-Liss, New York.

HERSHKOVITZ ; GREENWALD ; ROTHSCHILD ; LATIMER ; DUTOUR, JELLEMA ; WISH-BARATZ,

1999 - Hyperostosis Frontalis Interna: An Anthropological Perspective, "American Journal of Physical Anthropology", vol. 109, pp. 303-325.

HILLSON, S.

1996 - Dental Anthropology, Cambridge. Cambridge University Press.

INGELMARK, B. E.

1939 - The skeletons. in: Thordeman, B.; Norlund, P.: Ingelmark, B.E. "Armour from the Battle of Wisby". 136I. Stockholm. Uppsala.

LARSEN, C. ; SHAVIT,R. ; GRIFFIN, M.,

1991 - Dental Caries Evidence for Dietary Change: an Archaeological Context, in Kelley, M., Larsen, C., (eds), 1991, "Advances in Dental Anthropology", Wiley-Liss, New York.

LOPES, C. ; CUNHA, E.,

1998 - Necrópole da Quinta de S. Pedro. Análise antropológica de uma série do século XV. “Almadam", II. ' série. n. ${ }^{\circ}$ 7. pp. 37-44.

184 LOVEJOY, C. ; MEINDL, R. ; PRYZBECK, T. ; MENSFORTH. R.,

1985 - Chronological metamorphosis of the auricular surface of the ilium: a new method for the determination of adult skeletal age and death. "American Journal of Physical Anthropology", 68: pp.15-28.

LOVELL, N.

1997 - Traumo Analysis in Paleopathology, "Yearbook of Physical Anthropology", vol. 40. pp. 139-170. 
MARQUES, C. : CUNHA, E.,

2000 - "Anthropological analysis of a medieval population". In Varela,T. (ed.). Investigaciones en Biodiversidad Humana. Universidad de Santiago de Compostela. Sociedad Espanola de Antropologia Biologica, pp. 306-308 .

MATOS, V. ; CUNHA, E.,

1999 - A Necrópole do prazo no contexto das necrópoles medievais portuguesas. "Côavisão", n. ’ ', pp. 45- 51.

OLIVEIRA, General Frederico Alcide,

1988 - Aljubarrota Dissecada, $2^{a}$ edição, revista e ampliada. Lisboa, Direcção do Serviço Histórico-Militar.

OLIVIER, G. ; AARON, C. ; FULLY, G. ;TISSIER, G.,

1978 - New estimations of stature and cranial capacity in modern man. "Journal of Human Evolution", 7. pp. 512-518.

OWSLEY ; MANN ; MURPHY,

1991 - Injuries, Surgical care and Disease, in Pfeiffer e Williamson (ed), "Snake Hill: an Investigation of a military Cemetery from War of 1812", Toronto e Oxford, Dundurn Press.

PAÇO, AFONSO DO,

1962 - Em torno de Aljubarrota 1 - O problemo dos ossos dos combatentes do batalha, "Anais da Academia Portuguesa da História", II Série, vol. 12, pp. I| 4-163.

PÁLFI, G.,

1997 - Maladies dans l'Antiquité et au Moyen-Âge, "Bulletins et Mem. de la Société d'Anthropologie de Paris, t. 9. n. ${ }^{\circ}$ । e 2.

PÁLFI, G. ; DUTOUR, O.,

1996 - Activity-induced skeletal markers in historical anthropological material, "International Journal of Anthropology", vol. II, n. ${ }^{\circ}$ (4I-55).

PEYRON, J.; ALTMAN, R.,

1992 - The epidemiology of osteoarthritis. In: Moskowitz et al. (ed). "Osteoarthritis. Diagnosis and Medical /Surgical Management". London. W. B. Saunders.

ROBERTS, C. ; MANCHESTER, K.,

1995 - The archoeology of Disease, Ithaca, New York, Alan Sutton Publishing Limited, Cornell University Press.

ROBERTS, C.,

1991 - Traumo and treatment in the British Isles in the Historic Period: A design for multidisciplinary research. in: Ortner,D.J. and A.C. Aufderheide, 1991. "Human 
Paleopathology: Current synthesis and future options". Washington. Smithsonian Press. pp. 225-240.

SANTOS, A. L.,

1993 - Diagnose sexuelle et estimation de la longuer du fémur d'après l'étude de quelques de ses fragments, Poster Apresentado no Congresso GALF, Bordeaux. SERJEANTSON, D.,

1991 - Rid Grosse os Bones : A taphonomic Study of the Bones from Midden Deposits at the Neolithic and Bronze Age Site of Runnymede, Surrey, England. "Int. J. of Osteoarchaeology", 1 : pp. 73-89.

SILVA, A. M.,

1995 - Sex assessment using the calconeus and talus, "Antropologia Portuguesa", vol.13, pp. 107-119.

SMITH, B. H.,

1984 - Patterns of molar wear in hunter-gathers and agriculturalists. "American Journal of Phisycal Anthropology", vol. 63. pp. 39-84.

TAMAGNINI, E. ; VIEIRA de CAMPOS,

1949 - O fémur português, "Contribuições para o estudo da Antropologia Portuguesa", vol. II, fascículo I.

THORDEMAN, B. ; NORLUND, P. ; INGELMARK, B. E.,

1939 - Armour from the Battle of Wisby. 1361. Stockholm. Uppsala.

UBELAKER, D.,

1997 - Taphonomic applications in Forensic Anthropology. In: Haglund, W. D. ; Sorg, M. H. (ed), "Forensic Taphonomy", Bica Raton. CRC Press.

UBELAKER, D.,

1989 - Human skeletal remains: excavation, analysis, interpretation, Washington, Taraxacun. WAPLER, U.,

1998 - Cribra orbitalia in anthropobiology: diagnostic criterions and implications in the study of ancient skeletal populations. Thèse pour obtenir le grade de Docteur. Universitè Bordeaux I.

WILKINSON,

1997 - Violence against women: raping and abduction in Pré-historic Michigan, in Martin, D., e Frayer, D. (ed), "Troubled Times: violence and warfare in the Past", Gordon and Breach Publishers. 
ANEXOS 
(Página deixada propositadamente em branco) 


\section{REPORT OF RADIOCARBON DATING ANALYSES}

\begin{tabular}{rccc}
\hline Sample Data & $\begin{array}{c}\text { Measured } \\
\text { C14 Age }\end{array}$ & $\begin{array}{c}\text { C13/C12 } \\
\text { Ratio }\end{array}$ & $\begin{array}{c}\text { Conventional } \\
\text { C14 Age }\left(^{*}\right)\end{array}$ \\
\hline Beta-129710 & $500+/-50 \mathrm{BP}$ & $-19.0^{\star} 0 / 00$ & $600+/-50^{\star} \mathrm{BP}$
\end{tabular}

SAMPLE \#: ALJUBARROTA

ANALYSIS: radiometric-standard

MATERIAL/PRETREATMENT: (bone collagen): collagen extraction (acid only)

NOTE: It is important to read the calendar calibration information and to use the calendar calibrated results (reported separately) when interpreting these results in $A D / B C$ terms. 
ANEXO 2

\title{
CALIBRATION OF RADIOCARBON AGE TO CALENDAR YEARS
}

(Variables: est. $\mathrm{C} 13 / \mathrm{Cl} 2=-25:$ lab. mult $=1$ )

\author{
Laboratory number Beta- 129710 \\ Conventional radiocarbon age ': $600 \pm 50 \mathrm{BP}$ \\ 2 Sigma calibrated result: $C a l \bar{A} D 1290$ to 1425 (Cal BP 660 to 525) \\ ( $95 \%$ probability) \\ Cl3/Cl2 ratio estimaled
}

Intercept data

Intercepts of radiocarbon age

with calibration curve: Cal AD 1325 (Cal BP 625) and

Cal AD 1345 (Cal BP 605) and

Cal AD 1395 (Cal BP 555)

1 Sigma calibrated result: Cal AD 1300 to 1410 (Cal BP 650 to 540) (68\% probability)

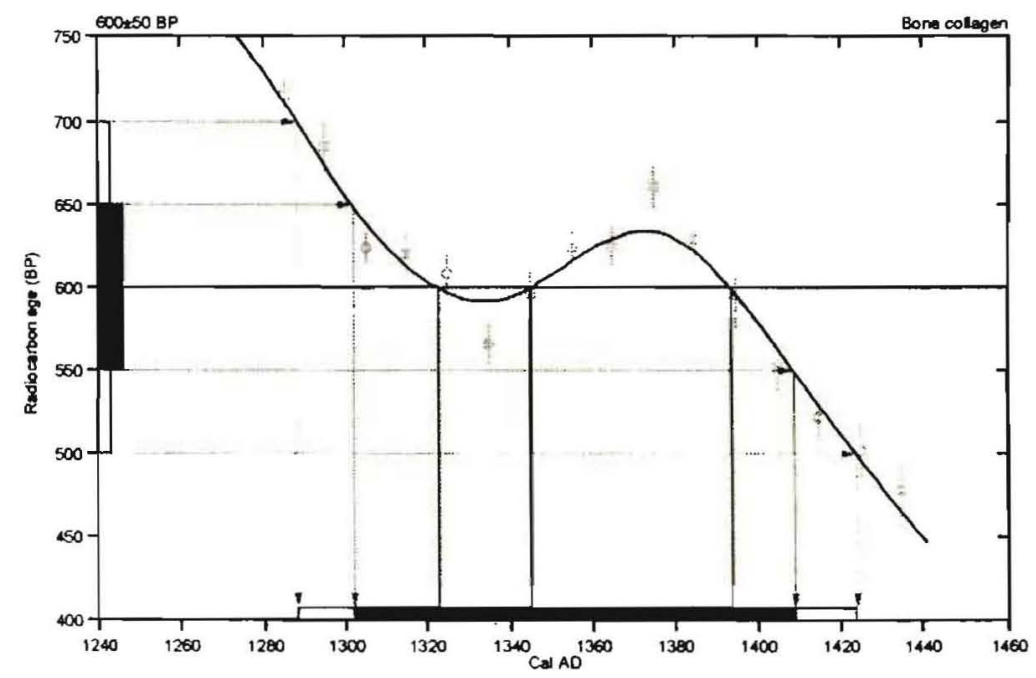


ANEXO 3

RESULTADOS OBTIDOS POR ANÁLISE PORACTIVACÃ̃ COM NEUTRÕES

\begin{tabular}{|l|r|r|}
\hline Elemento & Con. $(\mathrm{mg} / \mathrm{Kg})$ & Erro $(\mathrm{mg} / \mathrm{Kg})$ \\
\hline $\mathrm{Al} \%$ & 0.283 & 4.00 \\
\hline $\mathrm{As}$ & 111.100 & 4.40 \\
\hline $\mathrm{Br}$ & 3.190 & 0.21 \\
\hline $\mathrm{Ce}$ & 195.200 & 7.80 \\
\hline $\mathrm{Cl} \%$ & 0.220 & 4.00 \\
\hline $\mathrm{Co}$ & 89.300 & 3.60 \\
\hline $\mathrm{Cu} \%$ & 0.120 & 4.20 \\
\hline $\mathrm{Fe} \%$ & 73.500 & 4.00 \\
\hline $\mathrm{Ga}$ & 14.580 & 0.63 \\
\hline $\mathrm{K}$ & 275.000 & 26.00 \\
\hline $\mathrm{La}$ & 0.520 & 0.02 \\
\hline $\mathrm{Mn}$ & 58.600 & 6.30 \\
\hline $\mathrm{Na}$ & 231.100 & 9.20 \\
\hline $\mathrm{Rb}$ & 58.000 & 19.00 \\
\hline $\mathrm{Sb}$ & 7.220 & 0.37 \\
\hline $\mathrm{Sc}$ & 0.350 & 0.06 \\
\hline $\mathrm{Sm}$ & 0.070 & 0.01 \\
\hline $\mathrm{Sr}$ & 5.770 & 196.00 \\
\hline $\mathrm{W}$ & 0.520 & 0.21 \\
\hline $\mathrm{V}$ & 10.470 & 0.66 \\
\hline & & \\
\hline
\end{tabular}

Os resultados obtidos indicam o ferro como metal principal, sendo também o alumímio, o cloro e o cobre componentes importantes. Cerca de 25\% não foram identificados, podendo eventualmente ser chumbo que a nossa técnica de análise por activação com neutrões não detecta. 
Srife

investisacaio

Imprensa da Universidade

2001 